\title{
Transforming everyday life: Islamism and social movement theory
}

\author{
Cihan Tuğal
}

Published online: 3 June 2009

(C) The Author(s) 2009. This article is published with open access at Springerlink.com

\begin{abstract}
The Islamist movement in Turkey bases its mobilization strategy on transforming everyday practices. Public challenges against the state do not form a central part of its repertoire. New Social Movement theory provides some tools for analyzing such an unconventional strategic choice. However, as Islamist mobilization also seeks to reshape the state in the long run, New Social Movement theory (with its focus on culture and society and its relative neglect of the state) needs to be complemented by more institutional analyses. A hegemonic account of mobilization, which incorporates tools from theories of everyday life and identity-formation, as well as from state-centered approaches, is offered as a way to grasp the complexity of Islamism.
\end{abstract}

How do movements generate power? Can we talk about a social movement in the absence of contentious politics? How can a movement win the hearts and minds of a population even when it avoids challenging authorities? When we think of social movements, we tend to invoke images of rallies, demonstrations, strikes, and street action that challenge the state (McAdam 1988; Piven and Cloward 1977; Tilly 1978). Here, I draw attention to another kind of movement activity.

In Turkey, the Islamist movement generally shies away from challenging the state directly and usually avoids noisy protest. Why don't Islamists in Turkey directly attack secular authorities? How do they sustain mobilization under unfavorable circumstances?

Unlike the other established perspectives in social movement studies, the New Social Movements literature has put the transformation of identities at the center of analysis (Melucci 1996a). Rather than studying the state as either the inciter or target of mobilization, this literature demonstrates that movements can lead to social change by focusing on culture and society (Cohen 1985). Although this is a helpful

C. Tuğal $(\bowtie)$

Sociology Department, 410 Barrows Hall, Berkeley, CA 94720-1980, USA

e-mail: ctugal@berkeley.edu 
point of departure for understanding cases such as Turkish Islamism, it can lead us to neglect how the state is still central to the process of mobilization, even when it is not openly challenged.

Islamists did not deny engagement with the state, a denial that is built into the definition of "new social movements" by Alberto Melucci (1989) and others. Identity-formation was not an exclusive goal, but was tightly linked to desires about restructuring the state and the economy in Turkey. Islamist mobilization was therefore characterized by a contingent concentration on everyday life before becoming ready to deal with the state.

Despite attempts at integrating culture into the state-centered process approach to mobilization, certain theoretical separations still influence the way we think about social movements. While one influential strand of social movement theorization has focused on the generation of mobilization through targeting the state, another has centered on the generation of power through work on civil society. My main goal is to cast doubt on this separation. Although some of the old oppositions in the literature (such as those between culture and structure, identity and strategy, etc.) have been recently questioned, one binary opposition remains central, that between society and the state. Focusing on the state or society tends to be one of the main differentiating points between process and identity accounts of mobilization. Blurring this distinction may allow us to look at the separation between structure and culture from a different angle also. In this article, I bring in a hegemonic perspective to help us to rethink such binaries by integrating the lessons of the New Social Movements literature with the insights of process models.

\section{Models in the study of social movements}

Below, I underline how the New Social Movements literature has highlighted the importance of transforming everyday life for social movements and for the generation of power. Then, I use the political process model to point out what it misses: state structures, institutional venues, and resources are crucial both in the formation of a movement and in its strategies. Finally, I introduce hegemony as a framework that takes note of both the centrality of everyday life and the indispensability of the state (both as an object of analysis and as a target for some movements).

\section{New social movements}

The works of European scholars, especially Jean Cohen (1985), Jürgen Habermas (1987), Melucci (1989), and Alain Touraine (1981), have pointed out that at the end of the twentieth century movements have shifted from targeting the state to targeting society and everyday life. Movements no longer focus on the economy and institutional politics, they contend: they develop within civil society. Whereas old social movements were either directed against the state or demanded state power (Offe 1985), new social movements are no longer "political" in this sense. They find 
original ways of linking the personal, the national, and the global through bypassing the state. ${ }^{1}$

The central focus of social movements, according to this literature, has become the creation of identity. ${ }^{2}$ Identity is, as these scholars see it, the self-definition of the contending group, a definition chosen by the actors themselves. The drive of movements, according to Melucci, is certain questions that have to do with boundaries and consciousness, rather than the reform or appropriation of institutions: Who are we? What are our goals and means? (Melucci 1989, 1996a) ${ }^{3}$

The strength of this approach to social movements is that it notes an important transformation in the focus of social movements, seemingly away from the state and the economy and toward civil society and identity politics. This shift of emphasis from disruptive public confrontation with authorities to the challenging of dominant codes and creation of new meanings (Melucci 1996a, pp. 202-203) is crucial if we want to understand Islamism.

Yet, this literature's assumption that social autonomy has expanded so much that actors can create social identity without interference from powerful parties could be questioned even in Western Europe; when it comes to Islamism, this presupposition is much more problematic. In all predominantly Muslim countries, the states (along with the global hegemon, the United States) have participated in the constitution of Islamic actors. There were no self-constituting social movement subjects, as in the models of Melucci, Touraine, and Cohen.

Another problem is that this approach might be downplaying how some contemporary movements still target the state in roundabout ways even when they do not challenge it publicly. Therefore, state-centered social movement theories, as well as other theories of politics that focus on the state, are still relevant for cases such as Islamism.

\footnotetext{
${ }^{1}$ For the differences between the North American and Western European contexts of social movements theorization, see Diane Davis (1999). Despite the differences noted by Davis, the move away from the state and the economy in the theorization of mobilization is also observable in the American uses of identity theory (Epstein 1996; Taylor and Whittier 1995). Yet, there are important exceptions to this. Although Paul Lichterman's (1996) book The Search for Political Community (especially chapters 5 and 6) focuses broadly on the relation between political projects and personal life, there are clues in this book about how American environmental movements link everyday life and the state (also see Taylor 1989).

2 The emphasis on the dynamic and active creation of identity differentiates the work of Melucci from what has been criticized as "identity theory" and its assumption of coherent, stable, and rigid identities (Meeks 2001). Invoking the Bourdieusian criticism of identity theory by Brubaker and Cooper (2000), I use identity as a category of practice rather than a category of analysis, and therefore talk of "identity politics," "identity work," or "identity-formation" rather than simply "identity."

${ }^{3}$ While I concur with this emphasis on identity, I also submit that these questions (and the answers to them) are not always posed at the conscious, cognitive level, but are embedded in habits and practicesthough they might pass the threshold of consciousness in certain situations. Therefore, research should focus also on "the principles of division" (Bourdieu [1972] 1977) that mark the boundaries between "us" and "them" (which are conveyed in everyday practice and speech), rather than only looking at how activists choose to define the group and its others through conscious discourse. Melucci (1996b) does recognize the importance of habits and practices in his book The Playing Self, but he has not integrated the insights of this book to his theorization of mobilization. (See King [2004] for an attempt in this direction.) Despite the NSM literature's more thorough focus on consciousness, there are scholars in this tradition who squarely focus on everyday practices such as clothing, (not) shaving, treatment of others, gestures, and haircut (Taylor and Whittier 1992; Whittier 1995).
} 
Finally, the identity politics model tends to be too restrictive in its emphasis on the democratic mode of operation of social movements. For example, Cohen (1985, pp. 707-710) differentiates between pre-modern, old-style defenses of the life world $^{4}$ (which protected the existing, traditional communities) and new social movements that defend associational, reflexive, democratizing, and self-limiting life worlds against the encroachment of the market and the state. ${ }^{5}$ I propose that Islamism resembles a new social movement as it produces collective identity in a reflexive manner and through associational activities (rather than depending on received religious wisdom and existing communities), while it falls short of the perfect model since it is not a self-limiting and democratizing project. Therefore, in analyzing Islamism, we can integrate aspects of the New Social Movement (henceforth NSM) approach, but cannot adopt it in its entirety.

If we want to globalize the NSM framework and move it beyond its initial Western European and North American contexts, we have to be more flexible about these three issues (the state as one of the creators of identities; the state as one of the targets; movements' modes of operation). Process scholars have started to address "the core democracy bias" of their model (McAdam et al. 2001). Similar work needs to be done with the NSM approach to make it more globally relevant.

\section{Theories of political opportunity and resource mobilization}

The state is at the center of the political process paradigm, which was developed mainly by Charles Tilly (1978), Doug McAdam (1982), and Sidney Tarrow ([1994] 1998). Tilly (1995a) and Tarrow (1993) have forcefully argued that social movements emerged in the nineteenth century as a result of the centralization of states and have taken the states as their targets. ${ }^{6}$ Along these lines, Tilly (1984, p. 304 ) has influentially defined a social movement as "an organized, sustained, selfconscious challenge to existing authorities." 7 The focus of this literature is how social movement actors strategically (and in most cases rationally, see McAdam [1982, pp. 37, 39] and Tarrow [1998, p. 24]) make use of contingent opportunities provided by the political structure, and especially by the state (whence the model's other name, political opportunity structures, henceforth $\mathrm{POS}^{8}$ ).

Complementing the POS model, the resource mobilization (RM) approach has emphasized that the availability of organizational venues, expertise, time, financial

\footnotetext{
${ }^{4}$ Cohen critically builds this discussion on Habermas's opposition between the life world (the experienced, informal, intimate, communicative level of social life) and the (formal and rationalized) systems (such as the state and the economy).

${ }^{5}$ Even when Habermas (1996) and Cohen and Arato (1992) recognize the interdependency between society and state as targets, the model of social movements they develop remains mostly prescriptive rather than being analytical. Most crucially, they emphasize the egalitarian, communicative, and open nature of civil society and social movements, while the analyses below draw attention to how mobilization defines and institutes new patterns of domination and inequality while eroding older patterns. The normative dichotomies that Habermas provides (e.g., coerced vs. free public spheres) are inadequate to decipher the processes of naturalization-denaturalization revealed by hegemonic analysis (see below).

${ }^{6}$ Others have elaborated these findings by broadening the comparative framework and integrating counter-movements to the analysis of interactions between movements and states (Kriesi et al. 1995; Meyer and Staggenborg 1996; Parsa 1989).

${ }^{7}$ Also see Tilly (1982, p. 26) and McAdam et al. (2001, p. 5) for parallel definitions.

${ }^{8}$ See Goodwin and Jasper (1999) for the different implications of using these two labels.
} 
assets, and elite sponsorship are central to the likelihood of mobilization (Gamson 1975; Jenkins and Perrow 1977; McCarthy and Zald 1977; Oberschall 1973). This focus on the strategic use of resources, missing in the identity approach, should not be left out of analyses of movements. Yet, the RM approach leaves out what the identity approach emphasizes. Just like the POS model, it handles actors as exclusively strategic and rational. Movements, it assumes, put resources to the service of already defined movement goals. ${ }^{9}$ To the degree that it touches on them, the RM approach handles identity and everyday life instrumentally: these do not constitute the primary foci of movement activity, but their deployment may become tools for inciting people (Morris 1984; Zald 1996). ${ }^{10}$ We need an approach, I claim, that recognizes the goal-creating as well as instrumental, the habits-transforming as well as state-targeting aspects of movements.

Although POS and RM models have increasingly tackled questions of culture (Auyero 2004, pp. 420-421), ${ }^{11}$ the scholars associated with these approaches have most of the time neglected how culture, everyday life, identity-formation, and habits might not only be resources, instruments, and aspects of society that are transformed as a result of mobilization, but the very focus of movement activity. ${ }^{12}$ A frequent response to such criticisms has been to belittle identity-oriented movements and explanations. For instance, Tarrow (1998, p. 204) has bemoaned the fact that the civil rights movement was universalist, whereas its contemporary inheritors are particularistic. "Movements that privilege identity ignore opportunities," he laments, and march on the English Department while the Right takes the White House. ${ }^{13}$ Such dismissals of identity politics unwittingly deploy the usual dichotomies between identity-formation and macro-politics. They neglect that the Right that was taking over the White House had its own identity politics, which was mobilized through churches, associations, and think-tanks, if not through English departments. Yet, these dismissals do have an element of truth, in that an exclusive focus on "the English Department" (a metaphor that captures identity-formation, language, civil society, and the everyday) if coupled with an evasion of "the White House" (that is,

\footnotetext{
${ }^{9}$ For a similar instrumentalist approach to the question of how a movement frames its goals, see Benford (1993), Gamson (1988), and Snow et al. (1986).

${ }^{10}$ Other scholars working on American and British cases have problematized the givenness of movement goals and demonstrated how they are constituted through narrative, thinking, and dialogic discourse (Polletta 1998a, b, 2006; Schurman and Munro 2006; Steinberg 1998, 1999), yet everyday life and bodily practice has been marginal to their accounts.

${ }^{11}$ See especially Tilly $(1986,1995$ b) on learning and repertoires. Also see later attempts to bring framing, RM and POS literatures together, thereby integrating culture to the very heart of political processes (Gamson and Meyer 1996; Kurzman 1996).

12 The contentious politics model developed by McAdam et al. (2001) has integrated the analysis of identity to process models, but still holds that the important cultural work occurs after the mobilization is triggered by broader changes and by the emergence/perception of opportunities and threats (pp. 47, 48). McAdam et al. take identity as mostly shaped by public and dramatic contention, and do not look at preceding identity work, which might have prepared subjects for contention (pp. 55-63; also see pp. 167169, 244-246). While they recognize in passing that creation of movement targets and identities also occurs "over the long run and outside of contentious interaction" (p. 144), no tools are provided for the analysis of such creation. Schurman and Munro (2006) have also drawn attention to the lack of theorization regarding this pre-contentious phase of mobilization in political process explanations.

13 The metaphor belongs to Todd Gitlin (1995), who criticizes the excesses of identity politics.
} 
politics proper and the state) would be fatal-for movements as well as for the analyses of movements.

Integrating culture into the institutional

Several scholars have already called for combining the insights of POS, NSM, and other cultural approaches more rigorously (Goodwin and Jasper 1999; Meyer et al. 2002; Mueller 1992; Voss 1996). I aim to contribute to this integrative turn by i) drawing attention to everyday practices as a site of contention ii) underlining how some movements attempt to transform both society and state. Below, I briefly discuss some major contributions to the integrative turn and point out what can be developed further in these accounts.

Two influential edited volumes (Goodwin and Jasper 2004a; Johnston and Klandermans 1995) have discussed several elements of culture and how they influence mobilization. These elements include symbols, codes, identity, narrative, discourse, ideology, and frames. I suggest that, in the case of some movements, everyday practices are more central than these elements. The contributors to one of these volumes come close to the perspective developed here when they discuss rituals (Fine 1995, p. 131; Swidler 1995, pp. 27-29; Taylor and Whittier 1995, pp. 175-180). Taylor and Whittier (pp. 164, 173-174) go further than the others in highlighting the politicization of everyday routine, especially in lesbian feminist movements. Here I expand on Taylor and Whittier's insights by developing their emphasis on practices.

More recently, Francesca Polletta (2006) showed that the cultural aspects of movements also create interests, rather than just furthering them. She has also demonstrated how cultural form can be a target rather than just a resource for movements (Polletta 2002). I take this insight and extend it to the level of everyday practices. ${ }^{14}$ Furthermore, just as Polletta (2002, pp. 7-10) shows there is no necessary trade-off between political virtue and political strategy, I show that for the Islamists there was no trade-off between targeting everyday life and targeting the state (as an NSM scholar might expect).

Together with these recent advances, Cohen's early work provides one of the most thorough syntheses of the process and identity oriented approaches. Cohen (1985, pp. 708, 715-716) pointed out that most contemporary movements involved both an identity-creating component and a strategic/rational calculation component. The two major approaches to collective action, argued Cohen, suffered from neglecting one of these aspects and overemphasizing the other. Below, I build on Cohen's insights and seek to analyze the identity-creating and strategic components of Islamic mobilization in conjunction with each other.

However, I also point out that Cohen remained on the NSM perspective side and reproduced the differentiation between these approaches by differentiating between old movements that targeted the state and new movements that targeted civil society. Cohen $(1985$, p. 667) stated that new social movements "target the social domain of "civil society" rather than the economy or state, raising issues concerned with the

\footnotetext{
${ }_{14}$ Polletta (2002, pp. 16-20, 221-222) looks at how everyday life (routine forms of decision-making, conflict resolution, etc.) influences movements, but not at how movements transform everyday life.
} 
democratization of structures of everyday life and focusing on forms of communication and collective identity." I seek to go beyond Cohen by pointing out that some movements target both society and the state.

Coming from the other angle, scholars who have criticized or extended the political process approach have questioned many of the conceptual separations in the field. Among them, James Jasper (2004) has blurred the distinction between identity and strategy and (like Cohen) argued that these are interlocking aspects of a movement. ${ }^{15}$ Goodwin and Jasper (2004b, pp. 88-91), Polletta (2004), and Marc Steinberg $(2004$, pp. 124-129, 132) have also questioned the binary opposition between culture and structure. I draw on these insights below. However, the civil society/state binary remains intact in most of this work, and the state is allegedly the primary target of movements. This article contributes to these integrative attempts by handling political processes and "politics proper" (the targeting of states, municipalities and other explicitly political institutions) on the one hand and "identity politics" (or, in our case, the politics of everyday practice) on the other as the intertwined moments of hegemonic politics.

\section{Hegemonic analysis}

I contend that, in the case of certain movements, mobilization for a sociopolitical purpose can be handled as the formation of an alternative hegemony. I define "hegemony" by modifying Antonio Gramsci's (1971) conceptualization: the organization of power in society and state through the constitution and naturalization of an everyday routine (also see Laitin 1986). I take the state as the interlinked set of institutions (including the government, local governments, the military, the police, courts, etc.) that organize domination in a polity through policy-making, coercion, regulation, and consent; and I take society as the associational groupings that mediate between the state and the economy (including family and kin networks, nongovernmental organizations, informal networks, religious institutions, educational institutions, etc.). ${ }^{16}$ In the case of the movements that I will call "hegemonic," the reorganization of everyday practices is interwoven with the transformation of the state. So, some social movements attack both society and state through denaturalizing everyday life and constituting an alternative everyday routine.

Social analysts have previously used hegemony in the sense of a cultural blinder that prevents the emergence of coherent and critical consciousness (Gaventa 1982, pp. 19-20; Gramsci 1971). Hegemony, in this account, prevents "issues from arising, grievances from being voiced, and interests from being recognized," especially through influencing the perceptions of the dominated and their conceptions of issues

\footnotetext{
${ }^{15}$ While my use of the term "strategy" here is similar to Jasper's in emphasizing the institutional and cultural contexts of strategy, mine differs by focusing less on conscious and explicit decision making, and more on practical logics of position-taking. In this sense, my use has more parallels with Bourdieu's (1977), though Jasper (1997) also relies on Bourdieu in his definition of strategic choice. Also see Clemens (1993, 1996).

${ }^{16}$ However, this is only a heuristic distinction, and the content and form of the differentiation between society and state depends upon political context and struggles (Mitchell 1999).
} 
(Gaventa 1982, pp. vii, 1, 12-13, 63, 114). Here, I shift attention from the consciousness and minds of individuals to the naturalization of practices. ${ }^{17}$

The concept of hegemony captures how power is constituted in both state and society. State and society are intertwined in this process: they are not additive. It follows that hegemonic mobilization reconfigures state and society through a long walk, which concentrates on repetitive conversations, oral debates, readings (of newspapers, books, pamphlets), education, rituals, and routinized everyday practices, and which only infrequently leads to explosions. This is the rarely recognized, "molecular" dimension of mobilization that is too easily ignored because of our focus on street action. ${ }^{18}$ But, in many cases, this street action presupposes the formation of a collectivity through inculcated dispositions. Grievances are not omnipresent, as political process theorists assume (Hafez 2003; McCarthy and Zald 1977; Tilly 1978); they are constructed by movements (Schurman and Munro 2006).

Hegemonic mobilization is formative of actors. According to this framework, the most important resources are those that allow the movement to institute alternative daily routines. Yet, the organization of hegemony, which is necessarily a process of identity-formation, goes beyond the creation of identity (as the NSM scholarship understands it), as its terrain of struggle encompasses state and society. Table 1 situates the hegemonic approach to mobilization with respect to POS and NSM approaches.

A potential weakness in Gramsci's theorization of hegemony calls for combining his and Pierre Bourdieu's insights. Whereas Gramsci handles the formation of hegemony mostly in terms of consciousness and awareness, habits and (conscious, semiconscious, or unconscious) everyday strategies are also crucial in the constitution of a hegemonic collectivity. ${ }^{19}$ These everyday practices result from embodied principles of division, which are inculcated in actors through (politically guided)

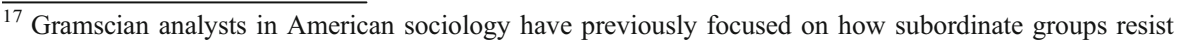
hegemony and achieve autonomy (Billings 1990, p. 3). My concern, rather, is how religion might become the prime mover of an alternative hegemonic project through transforming everyday life and constituting the subjects (rather than only shaping worldviews, as in Billings, Gaventa, and most Gramscian literature). ${ }^{18}$ Other scholars have problematized the exclusive focus on street action, but this has mostly taken the form of pointing out how institutional politics spills into transgression, or how the boundary between the two is maintained and contested (O'Brien 2003) rather than looking at the interlinkages between everyday life and transgression. McAdam et al. (2005) have recently problematized the focus on disruptive protest and suggested that we readjust our lenses to also look at peaceful protests - a suggestion that still leaves everyday work outside of the purview of social movement theory.

${ }^{19}$ Scholars from diverse intellectual traditions have noted the centrality of everyday life to the reproduction of society (Bellah et al. 1985; Melucci 1996b; Smith 1987). They have argued that habits and everyday practices naturalize social and political systems (Bourdieu [1980] 1990; Lefebvre ((1947) 1991). The literature on everyday life and practices is broad, and an article-length treatment of social movement theory cannot possibly do justice to it. My emphasis on Bourdieu rather than other key theorists of the everyday is due to his exploration of strategy in a structural context, which differentiates him from those who see everyday life as almost completely shaped by the development of capitalism or stateformation (Elias [1939] 2000; Lefebvre ((1947) 1991). and those who attribute infinite malleability to everyday practices (de Certeau [1974] 1984; Goffman 1959; Scott 1985).
} 
Table 1 Approaches to mobilization

\begin{tabular}{|c|c|c|c|c|}
\hline & $\begin{array}{l}\text { Empirical } \\
\text { focus }\end{array}$ & $\begin{array}{l}\text { Explanans } \\
\text { of movement } \\
\text { emergence }\end{array}$ & $\begin{array}{l}\text { Target of } \\
\text { movements } \\
\text { under } \\
\text { scrutiny }\end{array}$ & $\begin{array}{l}\text { The role of } \\
\text { cultural work }\end{array}$ \\
\hline $\begin{array}{l}\text { The political } \\
\text { process } \\
\text { approach }\end{array}$ & $\begin{array}{l}\text { Dramatic instances of } \\
\text { mobilization/ the reform or } \\
\text { appropriation of institutions }\end{array}$ & $\begin{array}{l}\text { Changes in the } \\
\text { structure of the state } \\
\text { and the availability } \\
\text { of resources }\end{array}$ & State & $\begin{array}{l}\text { Instrumental } \\
\text { (identity and } \\
\text { frames as } \\
\text { "resources") }\end{array}$ \\
\hline $\begin{array}{l}\text { The New } \\
\text { Social } \\
\text { Movements } \\
\text { approach }\end{array}$ & $\begin{array}{l}\text { The creation of identity/ } \\
\text { transformation of } \\
\text { everyday practices }\end{array}$ & $\begin{array}{l}\text { Successful bottom-up } \\
\text { mobilization of } \\
\text { identity }\end{array}$ & Society & $\begin{array}{l}\text { Formative of } \\
\text { movement actors }\end{array}$ \\
\hline $\begin{array}{l}\text { The } \\
\text { hegemonic } \\
\text { approach }\end{array}$ & $\begin{array}{l}\text { The reform or appropriation } \\
\text { of institutions through the } \\
\text { transformation of everyday } \\
\text { practices }\end{array}$ & $\begin{array}{l}\text { Unintended fusion } \\
\text { of the state's and } \\
\text { movement actors' } \\
\text { regulating activities }\end{array}$ & $\begin{array}{l}\text { Society, state, } \\
\text { economy }\end{array}$ & $\begin{array}{l}\text { Simultaneously } \\
\text { formative and } \\
\text { strategic }\end{array}$ \\
\hline
\end{tabular}

socialization as collective dispositions. ${ }^{20}$ And just like the awareness, the dispositions too encompass society and state: they shape actors' relation to society as well as to the state. To put it differently, Bourdieu's theorization leads us to focus on actors' dispositions to divide and perceive time and space in specific ways. These tendencies of perception and division, in turn, give rise to a specific set of routine activities (which I here call everyday practices). Dispositions, more generally, include internalized tendencies to act in certain ways rather than others (reading the holy book at night rather than watching television, fearing and obeying God rather than the state, avoiding contact with the opposite sex, participating in political activities in one's district rather than spending the weekend with one's family, interrupting work when the call to prayer is read, etc.)

As seen below, once the flow of everyday practices is organized around prayer times, it takes less explicit ideological persuasion to make people pray, as their habits become self-perpetuating. Yet, even this self-perpetuation works best when it is regulated (though not necessarily ideologically imposed) by institutions like municipalities and local governments. Therefore, any theory of hegemony, and the understanding of hegemonic social movements, should include a discussion of everyday practices and rituals. ${ }^{21}$

\footnotetext{
${ }^{20}$ Here, I am drawing on Bourdieu's writings (1977, [1979] 1984) on strategies and the habitus (collective dispositions and principles of vision and division). That this socialization is politically guided under the influence of social movement activists, intellectuals, political institutions, and politicians is ignored in Bourdieu's work, which necessitates a fusion of his contributions with Gramsci's. While Bourdieu explains the dynamics of collective dispositions based on a primarily structural account, bringing in Gramsci allows us to focus on the partially political making of these dispositions-a supplement that complements and displaces Bourdieu's structural approach rather than replacing it.

${ }^{21}$ Emotions can also be handled as constituting a subset of the everyday practices and dispositions discussed in this article (see below for struggles over and experiences of fear, love, devotion, etc.). Similar to what I am proposing here, Elizabeth Perry (2002) and Deborah Gould (2002) have demonstrated how activists target both society and state through working on feelings. However, despite many empirical contributions (Goodwin et al. 2001), the scholarly work on emotions in social movements is only beginning to offer a comprehensive theoretical agenda (Emirbayer and Goldberg 2005).
} 


\section{Setting and methods}

The locality where I studied the Islamist movement, Sultanbeyli, is the district with the highest Islamist party votes in Istanbul (Turkey's largest metropolitan center). A village of 3,700 people before 1985 , Sultanbeyli had become a district of 80,000 by 1989. This has mostly been an informal development, and most of the buildings are still unregistered. While the district received rural immigrants from all parts of Turkey, immigrants from the Black Sea region and the Kurdish provinces in the East predominated, along with second-generation immigrants to the city from the same regions. The majority of the district is composed of primary school graduates (many of them concentrated in the construction sector) and its population is younger when compared to the rest of Istanbul (Işık and Pınarcıoğlu 2001, pp. 286, 288-289, 318319). Together with its political affiliation, the district's informal growth ${ }^{22}$ has made it a frequent target of secularist ${ }^{23}$ policy and criticism.

Located on the outskirts of the city (near Izmit, an industrial city to the east of Istanbul), Sultanbeyli is the first urban district to have an elected Islamist municipality. Before the late 1980s, Sultanbeyli had no dominant political or religious color. Like many urban districts, center-leftists (the Social Democratic Populist Party) and center-rightists (the Motherland Party) vied for power. The decisive politicization started after the mid-1980s, when religious people in provincial towns and villages heard about the Islamic educational activities in the district and immigrated to Sultanbeyli in networks of family, kin, and religious community. Islamist activists spread the word as far as Erzurum (a provincial region of Eastern Turkey) in the East and Germany in the West, and many families bought land in the district without ever having seen it. Immigrant women were also active in attracting relatives to the district, by telling them that this was the primary site of religious awakening in Turkey. In short, the interaction between politics and (kin and religious) networks was central to the creation of an Islamic district.

The (Islamist) Welfare Party controlled the municipality after the elections of 1989 , until a secularist coup in 1997. While there was political opposition to the Islamists throughout the 1990s (organized around the center-right True Path Party and the center-left Republican People's Party, and later the Democratic Left Party), this remained weak when compared to opposition from the military and the local government. One of the high moments of the struggle between the Welfare Party and the military revolved around an Atatürk statue. In Turkey, one can see Atatürk statues and busts in every public square, park, and official building. These remind citizens of the official commitment to the founding leader Atatürk's secular nationalism. $^{24}$ In 1996, the Sultanbeyli mayor Koçak removed the most visible Atatürk statue in the district from the main boulevard to a neighborhood park. The

\footnotetext{
$\overline{22}$ This rapid and informal growth was actually related to the district's political affiliation, as the Islamist municipality opened the way to informality in order to bring in as many people as possible and strengthen Islamism's base. Not all the incoming immigrants were necessarily Islamist to begin with, but some of them underwent a thorough process of Islamicization.

${ }^{23}$ In the Turkish context, secularism (laiklik) refers to the propagation of nationalism, capitalism, and Westernization through religious and non-religious channels, rather than a straightforward differentiation between religious and other spheres of life (Tuğal 2007; Davison 1998; Mardin 1989).

24 Özyürek (2006) provides a thorough analysis of how this symbolism has changed over the decades.
} 
military responded by storming the district with tanks and re-erecting the statue. After this point, Welfare Party authorities avoided any direct confrontation with the state.

Islamicizing activities in the district abated after the secularist military intervention of 1997, which restricted Islamic schools and religious orders throughout Turkey, in addition to closing down the Welfare Party, youth organizations, and some religious teahouses. After the intervention, Islamists organized in the Virtue Party, which had toned down its criticism of the establishment. Despite this moderation, the regime ratcheted up its pressure on the Islamists, and the Virtue Party was going through a split during the final stages of this study. The Virtue Party held municipal power in Sultanbeyli until it was closed down by the secularist courts in 2002.

The exceptionally intense politicization in Sultanbeyli makes the district a suitable case for studying the influence of politics at the everyday level. Yet it also gives an idea about the restrictions of this case and the generalizability and replicability of the findings: the results of this study might speak more to cases where movements have such a great affect that they call the fundamentals of the existing order into question. ${ }^{25}$

Participant observation is arguably the ideal way of conducting research about the practices of activists (Lichterman 1998), especially about routine everyday practices and dispositions that might not always pass the threshold of consciousness. These dispositions are not always accessible through surveys and interviews that depend on actors' accounts. Through participant observation at several sites in Sultanbeyli from the summer of 2000 to the summer of 2002, I collected material on the interactions between religion, politics, and movement dynamics. These sites-especially the municipality, mosques, workplaces, conferences, and religious teahouses-were among Islamism's main mobilizing structures in the district.

I studied the mosques of the district center and of peripheral neighborhoods through regularly attending Friday sermons and also observing regular community prayer services, which are held five times a day. I also focused on coffeehouses and religious teahouses, where unemployed men spend their days, and the employed come to socialize after they return home from work. In the municipality and the local Islamist party headquarters, I studied the interactions between Islamist functionaries and the people. I taught at a secular public school within the borders of the district, while also analyzing institutions of religious education such as state-sponsored clerical high schools, Qur'an schools (a rough equivalent of Sunday schools), and madrasas. My attendance at popular conferences was also crucial to my understanding of Islamism, as hundreds of people attended these in Sultanbeyli. The discussions of religion carried out here trickled down to debates in workplaces and teahouses, regulating residents' everyday behaviors.

I conducted fifty semi-structured, in-depth interviews, which mostly lasted one to one-and-a-half hours, where I asked fifty-six interviewees about their life in the district, their interpretation of religion, and their opinions on local and national politics. Due to the highly segregated life among the religious residents, I had more access to the male half of the district because of my position as a male researcher.

\footnotetext{
${ }^{25}$ The reader should also keep in mind the specificity of the time frame (2000-2002): Islamists had just gone through a military defeat in Turkey, even though Islamism was still intact as a project and popular in this district (which was less the case after 2002).
} 
While I could formally interview only three females, I had numerous interactions with the mothers of my students and the wives of a few of my contacts. The interviewees were chosen through snowball sampling. Both individual and group interviews were conducted. The individual interviews (a total of 47) comprised talks with 11 small merchants and shopkeepers, sixteen workers, two retired workers, three housewives, an imam (prayer leader), two religion teachers, three primary school teachers, three real estate dealers, three politicians, and three functionaries from the municipality. Of the three group interviews, two were with construction workers (in groups of two and three) and the other was with four recent graduates of Sultanbeyli's clerical high school.

I openly declared to the people I interacted with that I was in the district for purposes of research. My affiliation with an American university initially raised suspicions. However, working in the district as a teacher allowed me to build trust and networks. Renting an apartment near my school, I gradually moved beyond my initial contacts.

The data collected at these sites and through these interviews were used to reflect on, evaluate, and expand existing theories, employing the logic of the extended case method (Burawoy et al. 1991). I therefore take Sultanbeyli not as a microcosm of the Islamic world (based on which one could draw inferences to represent all Muslims), but as a case from which the analyst can extend to larger structural forces and theoretical questions, by recognizing the locality's specificity. ${ }^{26}$ I will thus use the Sultanbeyli case to rethink some of the conceptual oppositions in the field of social movements and discuss how insights from a hegemonic framework can contribute to casting a doubt on them.

In the next section, I outline the role of the state and socioeconomic changes in the making of Islamism. In the following sections, I analyze how Islamists shape everyday life and its rhythms in a variety of settings. I then look at how this reconstruction of the everyday is linked to institutions and public offices.

\section{Macro-determinants of Islamist strategies}

Scholars who have used political process models to explain the dynamics of Islamism have tended to reduce this movement to a rational response to political conditions, or at best a wise use of Islamic frames to exploit political openings and resources (Alexander 2000). ${ }^{27}$ They have thereby neglected the everyday religious work done by Islamism, or this has constituted a lesser focus when compared to questions of framing, networks, resources, or political opportunities (e.g., Singerman 2004, p. 151; but see Clark 2004). Other work in this vein has analyzed culture and religion more thoroughly, while however still retaining a focus on movement activities oriented toward the state, rather than studying these in conjunction with

\footnotetext{
${ }^{26}$ Again following the extended case method, I emphasize process and context over reliability and replicability, and theory reconstruction over representativeness (Burawoy 1998).

27 Two articles that employ social movement theories have criticized this reductionism, but have not proposed satisfactory theoretical alternatives (Kuru 2005; Munson 2001).
} 
how Islamic mobilization transforms everyday life (Wickham 2002; Wiktorowicz 2004).

Those others who have approached the topic with a Touraineian bent have explored the everyday dimension of the movement, but have not theorized adequately the constitutive role of the state in the making of Islamism (Göle 1996). Other civil society-oriented analyses — such as Jenny White's (2002) analysis of Islamism in a district of Istanbul - privilege networks, culture, and identification over politics and the state, ignoring how all of these are constructed politically (and to an extent by the state).

The hegemonic approach emphasizes that the rise of Islamism had socioeconomic, political, and institutional determinants. The neo-liberal dismantling of agricultural support structures led to an influx of rural immigrants to already deindustrializing cities in the 1980s and 1990s (Keyder 1999). The incoming immigrants became more pious, partially as a result of the Islamist party's responsiveness to their economic needs and the repression of the Left that could speak to these needs. The Islamist party received less than $10 \%$ of the national vote before 1980, and its electorate was concentrated in the provinces. ${ }^{28}$ After it shifted its agenda to appeal to the rural immigrants, its votes increased to around 20 percent by the mid-1990s. Although apparently not very high, these votes granted the Welfare Party municipal and governmental power due to the extreme fragmentation of center parties. Wide-scale corruption, failure to resolve ethnic strife, and the impoverishment and dislocation resulting from structural adjustment programs had also discredited center-right and center-left parties, opening the way to the nationwide electoral success of Islamism.

In Istanbul, the last blow to the popular hope invested in the center-left was the incompetent municipal administration of the Social Democratic Populist Party (1989-1994), which culminated in one of the most symbolic Islamic electoral victories in Turkish history: the takeover of the Istanbul metropolitan municipality in 1994. Concomitant to this loss and the rise of Islamism, center-leftist parties shifted to an exclusive Kemalism ${ }^{29}$ (a rigid defense of Atatürk's principles), gradually moving away from the left-populist and social democratic elements they had incorporated starting with the 1960s. This left Islamist parties as the only channel for social justice politics in poor neighborhoods like Sultanbeyli.

Moreover, in the 1980s and 1990s, official mosques and appointed imams started to be insufficient and self-appointed imams with (underground) sufi, madrasa, or lay training filled in the gaps. Community-built and officially unregistered mosques sprouted all over the major cities of Turkey.

Certain sufi orders and madrasa scholars, along with many clerical school and theology school graduates who did not rise to prominent positions in top religious official institutions (i.e., the Directorate of Religious Affairs and theology schools), lined up behind Islamism against state-controlled, "official" Islam. This was the

\footnotetext{
${ }^{28}$ See Saribay (1985) for the platform and the electoral record of the relatively marginal Milli Salvation Party, which was a precursor to the popular Welfare Party.

${ }^{29}$ In the Turkish political lexicon, "Kemalizm" (Kemalism) is loosely, and not always consistently, differentiated from "Atatürkçülük" (Atatürkism). The latter refers to an overall abidance to Atatürk's principles, whereas the former connotes a more militant and assertive position, especially against Islamic activism. Kemalists claim that they are the only true Atatürkists.
} 
secular state's own doing to an extent, since it had created an inflation in clerical school graduates, with the main purpose of combating the Left, but did not create new positions of religious authority with high prestige or income that these new graduates could go into. Together with the state's ideological opening to Islam's politicization and deployment in public after 1980 (a "political opportunity," one could say), this structural change also contributed to the rise of Islamism. Such an involvement of the state in the creation of a movement would be incomprehensible from an exclusive NSM point of view, which requires us to bring in insights from both political opportunity and identity models by focusing on the state as one of the creators of identity (Meyer 2002).

The main Islamizing actors in Sultanbeyli were the Islamist party, imams, intellectuals, and tradesmen. Islamism was also the main tendency among the columnists and editors of the newspapers (Akit, Milli Gazete, Yeni Şafak) they followed. The officially appointed imams of the geographically central mosques tended to subscribe to official Islam. More radical varieties of Islamism ${ }^{30}$ were mainly the ideology of young graduates of theology schools and clerical schools. Some of these graduates were public school teachers; some worked in the local municipality; and some were unemployed. Most of them were either members of fringe groups, or had relations with them in their school years.

While the Islamist party and other movement organizations had several million members in the 1990s, they used the streets sparingly, only when religious liberties (e.g., veiling in schools) and institutions (e.g. clerical and Qur'an schools) were seriously threatened. This was partially due to the remarkable failure of the Left after fifteen years of street mobilization in the 1960s and 1970s. Islamists had learned from this experience that such politics was crushed pitilessly by the army, the police, and nationalist paramilitary groups; another route had to be taken. The weariness of ordinary citizens, who had been demoralized by the thousands of deaths during leftist mobilization, also necessitated a different strategy of mobilization. In this context, the poignant frame that the Islamists used, "peace (of mind) is in Islam," had broad resonance. ${ }^{31}$ Islamist street action further waned after the secularist military intervention in 1997, and was virtually non-existent during the 27 months I spent in the field. However, the alternative mobilization strategies of the Islamists, which depended on transforming everyday life rather than on confrontation with authorities, enabled the movement to persist even under the harsh post-1997 conditions. Despite sometimes unfavorable political conditions, these activists

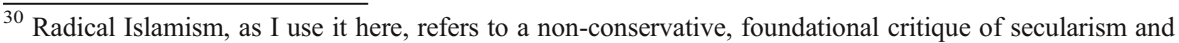
mainstream Islamism. What I call mainstream Islamism emphasizes the family, morality, and social harmony and seeks to accommodate traditional Islam. Radical Islamism, by contrast, demands a total transformation of Middle Eastern regimes and of traditional Islam, both of which they deem contrary to authentic Islam. See Tuğal (2006) for a more detailed differentiation.

${ }^{31}$ This frame is also telling in its difference from the more political and action-oriented key frame of the Egyptian and Jordanian Muslim Brotherhoods: "Islam is the solution" (Wickham 2002; Wiktorowicz 2001). Framing their appeal in this way helped Islamists in Turkey productively to "misrecognize" (Bourdieu 1977) their politics as apolitical, allowing them to thrive in a country where politics and politicians have lost all credibility. See Dawne Moon (2004) for a similar misrecognition of politics among North American religious communities.
} 
slowly Islamicized Turkey in the last two and a half decades, and paved the way for governmental power. ${ }^{32}$

\section{The Islamist politicization of everyday routine}

The constitution of hegemony via the strategic transformation of habits unfolds in contexts as varied as the street, the workplace, the teahouse, and the conference hall. I will provide an example of each below. Between 2000 and 2002, the main agent of this transformation was the (Islamist) Virtue Party and actors related to it, such as Metin, ${ }^{33}$ a street vendor. A former construction worker, Metin had started to sell cheap clothing after he retired. He did not perceive what he was doing as only business but also worship, and he engaged most of his customers in religious and political debates. With every call to prayer (three or four times during the working hours, depending on the time of the year), Metin would quit his car and run to the mosque, telling his customers that worship came before business. He was a member of both a well-established religious order (Iskenderpaşa Cemaati) and the Islamist party, which made him politically and religiously very dedicated. These belongings also conferred a sense of distinction and empowerment, which he emphasized by displaying signs of both his party and his order in his old and worn-out car, which he drove around for selling the merchandise.

Metin only had a primary school diploma, but persistently tried to go beyond the limits of his official degree. He had an ambitious reading schedule composed of the Qur'an, books about the life of the Prophet Muhammad, and texts regarding the history of the Ottoman Empire. He derived highly political messages from his readings:

We are a noble nation [millet] coming from a glorious past. Certain foci of evil are trying to destroy this nobility. Imperialist and Zionist powers are playing games on the people of Turkey. We are facing great dangers like forgetting religion, denying our essence, looking down on Islam. If believers read the Qur'an and understand it, they can overcome these dangers. The only way to set oneself free from difficulties of subsistence, the strengthening immoral current, from currents that degenerate humans, that destroy them, that deplete their spirit, that drive them to prostitution is to learn what you believe in ... from the source [implying classical religious sources].

Metin also told me that the state should encourage returning to "the sources." The most important difference between the contemporary Turkish state and the Ottoman state, according to him, was the lack of official support for religious practice and understanding, which caused the international power of Turkey to decline steadily. What we should note about Metin's daily practice is that he combines regular ritual,

\footnotetext{
32 This should not, however, create an impression of unproblematic success (White 2002; Yavuz 2003). While previous Islamists have indeed been in government for the last six years (2002-2008), this was possible only after serious concessions and a gradual shift away from Islamism.

${ }^{33}$ All private names are pseudonyms.
} 
commerce, and politics. He understands "the return to the sources" as the path that goes to personal salvation as well as the method that will strengthen Turkey. Along these lines, Metin encouraged his customers to develop a reading program like himself. His everyday routine, as instituted by the Islamist movement, is also a political routine: he does not differentiate tightly between economic practice and religious practice, and uses Islam to organize and give direction to his economic as well as religious routine, which he believes will create a more glorious, prosperous, and moral society and state. His everyday practices (his regular preaching to customers and his pressure on them to go to the mosque) therefore naturalize the hegemony of Islamic actors and call for their control of society and state.

This reshaping of everyday routine, both of one's own and of others, takes on a more contentious and more comprehensive color among more radical Islamists, among whom are Fikret and his friends. It becomes also more denaturalizing in its attacks against the religious and worldly lives of ordinary believers. I frequently spent time with Fikret in his real estate bureau, where he, his partner Hidayet (both of whom were in their forties), and his customers and friends regularly talked for hours about Islam, Islamism, and politics. Fikret and most of his friends were connected to the Islamist party (though ideologically they were critical of its pragmatism), the activists of which were also among his regular visitors. His office acted as one of the sites of opinion formation for the Islamists. Offices like this one are indeed one of the main resources of the Islamist hegemony: they naturalize an alternative everyday routine.

One day, Fikret and Mesut (one of his closest friends, a retired construction worker) were talking about how pious Muslims were less and less engaged in charity. Fikret reasoned that this was partially due to the attacks in the secular media against the fund drives through which many pious people sent huge sums of money to Bosnia. By arguing that these sums ended up in the treasury of the Islamist party and its leaders, the media had demoralized the Muslims, who were now less willing to partake in such campaigns. Hidayet was silent for a while, and finally declared that the problems were more deep-rooted than that:

None of us are like Muslims of Asr-l Saadet [The Age of Felicity] any more. We have too much property. We have too many apartments. People who love property [mala düşen] this much can't sacrifice themselves for Islam. Some people do go to war; it seems that they are sacrificing themselves. But actually, there is nobody doing it with ümmet [Islamic community] consciousness. Only some unemployed people go to the front because some rich Muslims give them money.

Hidayet is referring here to Asr-l Saadet, the times of the Prophet Muhammad and the first four caliphs, when (Islamists hold) belief came before everything else including property, the distribution of which was therefore egalitarian. While all pious Muslims believe that Asr-ı Saadet was the ideal age in Islamic history, only (radical) Islamists argue that Asr-l Saadet society was a classless society that contemporary Muslims should imitate by distributing their property or spending it for the sake of Islam. In Hidayet's account, the lack of ümmet consciousness - the consciousness that would require one to prioritize belief over property and restrict 
oneself from having too much property - is tightly linked to a particular experience of Islam as a religion:

Most people learn Islam from their mothers and fathers. Theirs is traditional Islam. The traditional Muslims who do not know [Islam] well enough think that they can save themselves from hell just by praying regularly. However, most of them commit shirk [associate other creatures with God] in practice and thereby commit the only sin that God will not forgive. God can forgive murder and theft, but the end of shirk is perpetual hell. They do not exactly obey God's laws but they obey traffic laws. They fear the police more than they fear God. Some of them love their wives more than God. All of this is shirk. [As one can easily slip into one of these,] all ulama [Islamic scholars] in Muslim history continually pleaded God not to condemn them to hell perpetually. All were content to burn for a while.

The Qur'anic term shirk, which is so central to radical Islamism, involves (depending upon the translation and interpretation) associating other creatures with God, implying that God has partners, or setting up partners in worship with God-a (sometimes) covert form of polytheism, which cannot be forgiven. ${ }^{34}$ According to non-Islamist Muslim scholars, shirk happens when a person explicitly treats another person like God (as might occur in the relations between a sufi master and his follower). Islamists, however, are harsher in their standards and argue that obeying anyone but God is actually shirk.

This long speech was addressed to me, as well as to Fikret and Mesut, so that we would understand what it takes to be a Muslim - and act accordingly. For Islamists like Hidayet, the aim of everyday interaction is to create subjects who do not fear the state and who apply (and call and fight for the application of) Islamic precepts and laws. These precepts should be learned by reading the written sources, rather than orally from the parents - which would break paternal authority and institute the authority of Islamist actors. It is not enough for Hidayet that the everyday life of a Muslim be characterized by praying five times a day. Islamic practice, according to him, also necessarily involves obeying all of God's ways and laws, even when (maybe especially when) they contradict the state's laws or a man's devotion to his family. This reconfiguration of everyday practice denaturalizes the regular dispositions of ordinary Muslims - their devotion to their families, to regular prayer, and to the religious knowledge acquired from their parents. It is this reflexive attack against the accustomed patterns of daily routine (so dear to the NSM literature) that makes the Islamist movement what it is. However, contrary to accounts that neatly separate culture from the economy and the state, Hidayet's involvement in the Islamist movement causes him to see his religion and his daily routine as tightly linked to the property regime. Changing the flow of everyday life brings with it changing the way society (and its relation to the state and the economy) is structured. Hidayet's religious interventions thus seek to introduce Islamic hegemony in familial relations and the economy, and weaken allegiance to the secularist state.

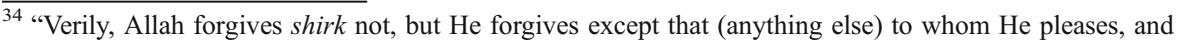
whoever commits shirk, he has indeed invented a tremendous sin" (Qur'an 4:48).
} 
Fikret and Hidayet had both worked for several years in Saudi Arabia while in their twenties. Residents with work experience in that country, and also those currently performing seasonal work there, were among the leading Islamicizers in Sultanbeyli. These figures had had the chance to see a more pious communal life in Saudi Arabia, had integrated aspects of this in their daily routines, and now sought to impose this on the rest of their own society. A more educated version of the same pattern could be seen among those who were trained in Pakistani madrasas and the Egyptian school al-Azhar. ${ }^{35}$ As different from previous workers like Fikret and Hidayet, the residents who had been to Pakistan and Egypt retained activist and intellectual networks with those countries. Ideas and strategies emanating from the Islamic movements in these countries influenced the mobilization in Sultanbeyli through such networks. Translated sources from leading Islamist movements in Pakistan, Egypt, and Iran (along with these transnational networks) boosted piety in the district.

In the larger context of the Islamist movement, the non-institutionalized identity work of residents such as Fikret and Hidayet is coupled with more institutionalized strategies, such as the publicly visible work on everyday practices that newspapers, magazines, and conferences carry out. An instance of this can be seen in Abdullah Y1ldiz's address to the public in Sultanbeyli. Y1ld1z was one of the main speakers of a conference organized by the Islamist intellectuals of the district. He is one of the main Islamist thinkers in Turkey, and the lead author of Umran, a radical Islamist religious and political magazine. In the last years, Umran and Y1ldiz were among those who set the tone for intellectual debates regarding Islamism in Turkey. In Sultanbeyli, Y1ldiz argued that the viable way of fighting imperialism was developing and strengthening the Islamic lifestyle:

The Islamic lifestyle based on modesty, frugality, contentment [kanaat], justice, balance, and sharing worries the West [which exercises the reverse of these values]. That is why the West is so aggressive against Muslims. Worship occupies a special place in this lifestyle. Prayer inculcates awe; fasting teaches one that s/he can stay hungry if need be. But Muslims do not spread this lifestyle through violence. The Prophet [Muhammad], for example, didn't force people to pray, but his attitudes and hal [demeanor] influenced people. For being able to present such a hal to non-believers, one has to win the war against one's nefis [self, flesh]. Otherwise, the war against evil [şeytani] forces (television, etc.) cannot be won. If we pray by knowing the meaning of the prayers, we can defeat the imperialists. Cevdet Said [a Syrian Islamic thinker] has already said that we should first look for the mistake in ourselves, not the imperialists. We are going to overcome the imperialists by first overcoming ourselves.

Notice that Y1ldiz is not inviting the residents of Sultanbeyli to boycott, protest, or attack the "imperialists"; rather, he is telling them to perfect their religion. While these proclamations, made before the 9/11 attacks, might sound outdated or even falsified in the light of the recent Islamist violence against (some institutions and

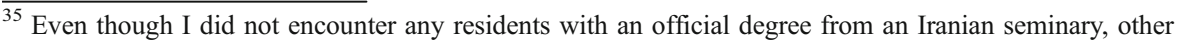
activists also had networks with Islamists in Iran.
} 
sectors of) the West, they should remind us that most Muslims (and even most Islamists) are still not engaged in armed violence against the West. Nevertheless, they also point out that Islamists code everyday religious practice itself in a contentious manner, which blurs the boundaries between what is and what is not contentious politics. Whereas we are inclined to see only street action as "mobilization," Islamist mobilization involves changing the patterns and rhythms of everyday life. Reference to the Prophet Muhammad is also quite telling here, as Islamists believe that his exemplary daily conduct did not only lead him to win and take over the hearts (and "identity") of his contenders and of third parties, but also the state of his rivals. In summary, Islamic hegemony seeks to counter Western domination through correcting the self, which will allow pious actors to exercise power over the non-pious - not by force, but by consent.

The division and re-organization of space

An analysis of how the Islamic movement refashions the use of social space will help us question some of the common binary oppositions in the social movement scholarship. According to Nilüfer Göle (1996), the distinctiveness of Islamic culture lies in its emphasis on closed spaces that make women less visible and contactable, thereby preserving communal morality (through controlling women's sexuality). The more Islamically oriented Sultanbeyli inhabitants built their neighbourhoods and apartments by keeping this precept in mind. Those who could afford it built gardens surrounded by high walls, which provided space for the socialization of women in a manner that would not be observable from the outside. A lot of poor immigrants, however, did not have the resources to finance such an architectural structure. The most conservative among them compensated for this disadvantage by building houses with windows that did not permit the visibility of the interior. Another architectural feature in some of these houses is the layout of the rooms, the doors of which are not immediately visible to each other. As a result of this layout, males who are not the members of its kin network can still visit a conservative family without necessarily encountering the female members of the household. Islamic mobilization differentiated this district from other districts of Istanbul, therefore, even at the architectural level. While my stance as a male researcher restricted my access because of this layout, my position in the district as a teacher allowed me to visit the parents of my students, temporarily eliminating the architectural barrier within certain limits.

This spatial differentiation is one of the goals of Islamicization, but it also creates the geographical resources for further female mobilization, together with subordinating women. Various layers of female practice in the district reproduce and negotiate this spatial configuration. The women of families that have settled without a wide network of relatives generally do not leave their streets. Their house visits are restricted, the neighbours see them as outsiders, and they have nobody to walk the streets of the district with. This leaves them without much to do, since they see the city as unpredictable and dangerous, which keeps them from going out by themselves.

Women with wide networks of relatives, on the other hand, frequently go on house visits. They know by heart the streets of the neighborhood because they have 
relatives spread across the district. They go in groups of neighbors to the bazaars of their own neighborhood and others, not only for shopping, but also for seeing relatives. Short house visits of relatives follow bazaar incursions in other neighborhoods.

These networks have their own drawbacks, however, since mechanisms of control over women also get more intense to the degree that the community itself is wide. Women with wide networks always have to take into account the opinions of their neighbors; they have to keep their houses tidy and clean, since they are always in interaction with others: anyone can visit them at any moment of the day. There is very little of what might be called personal space in their homes, since most of the space there is in community use.

Women living in small community networks, such as an apartment building of three stories of agnates as in Halime's case, feel the pressures of networks, without enjoying the benefits of community life: they are imprisoned in their buildings or streets, and are also under tight control. Halime's husband, who owns a small workshop, has married a young woman without divorcing Halime ${ }^{36}$ and settled in another district, leaving her with his brothers and their families in two adjacent apartment buildings. Her female as well as male kin who live on her street restrict Halime's contacts with outsiders. Halime expressed her restrictions poignantly as she told me the reason why she encourages her son (then in eighth grade) to pursue his studies:

In the village I wandered around more. Since I came here, I haven't done that. As I haven't gone to school I can't wander around in the city. I only know two streets beyond this one. I want him to be educated so that he can wander around.

As there is consistent emphasis in Turkish public discourse on the civilizing and liberating influence of education, rural immigrants sometimes blame themselves and their "ignorance" for their lack of freedom. Patriarchy, however, is not a legitimate target in conservative neighborhoods, which prevents Halime from criticizing the restrictions imposed by her kin network, let alone questioning the overall spatial structure of the district.

For women from conservative families, one strategy of expanding one's space within these restrictions is pushing religious reasoning to its logical conclusions and arguing that everybody, irrespective of gender, should work for God's glory. ${ }^{37}$ When this strategy is used, the political participation of women is specifically enabled through the architectural arrangement of the district: the space produced by the Islamic movement becomes a resource for women's religious mobilization. Under the current regime of segregation, their participation in political and public life is not perceived as a threat to morality or as an invitation to sexual permissiveness. Fatma, a young activist of the Virtue Party, told me that she enjoyed the district very much

\footnotetext{
${ }^{36}$ Polygamy, though prohibited by secular law, is still practiced in both urban and rural areas of Turkey (Yilmaz 2003).

${ }^{37}$ For the mixed blessings of this strategy, see Mahmood (2005).
} 
because she could go everywhere without being noticed too much by men. She added:

We would be suffocated in districts like Kadıköy [a central district of Istanbul]. We would be imprisoned within four walls. Here we can breathe. Thanks to sohbets and [Islamist] party activities, we can always go out. I have visited so many homes because of these activities.

Fatma also said that she started going out more after she became politically involved. Religious activism confers on women the right to get out, associate with others (even with those outside family networks) and organize, without leading them to question the overall spatial structures that constrain their actions.

The Islamic reorganization of space in this district casts a doubt on conceptual separations between identity-creation and strategy, and culture and structure. The specific architectural layout forged by Islamic mobilization is a part of identity formation, but (as in the case of many female activists) it also serves as a resource for further mobilization. Moreover, while clearly a part of the Islamicized culture of the district, the spatial patterns analyzed above also constitute a structure that both enables and restricts action in multiple ways.

The division and re-organization of time

The regulation of everyday life necessarily involves the control of the rhythm of that life. In Sultanbeyli, there is a naturalized flow of time that tends to naturalize the hegemony of the Islamists and denaturalize the secularist state. We can take the teahouses frequented by construction workers as an example. Construction workers come to the teahouses early in the morning. They wander around the blocks surrounding the teahouse. When a friend comes, they go back to the teahouse and buy him a cup of tea. When bored, they go out and continue their conversation on the pavement, by the wall. When they hear the call to prayer, they go to the mosque in small groups. After the evening prayer, they return home. During the month of fasting (Ramadan), they return at a later hour because they perform the additional collective prayer (teravih) that is specific to that month and is later in the evening.

For construction workers, the time between the prayers is somewhat stressful because they expect to hear about available work. During my time in the field, the construction business in Turkey was undergoing a severe crisis, first because of a major earthquake in 1999 that hit the sector specifically (due to tightened zoning regulations), and then the nationwide financial crisis in 2001. So, most of the time, the awaited calls were not forthcoming. When the hour of prayer arrived three or four times a day (the other regular prayers were performed at home), workers usually expressed relief. Dursun, a construction worker in his forties, captures how a structured religious routine gave a rhythm to life and supplied them with something to anticipate:

How can society be irreligious? There is a quake in beliefs during the last fourfive years. People are behaving weirdly and they are saying strange things. They will either go mad or commit suicide, since they lack religion. ... Unemployment is everywhere. We sit here [at the teahouse] for hours, in vain. 
... Religion gives a direction to people. It teaches us not to spend our time in vain. But when this direction-giving religion strengthens, they block it!

This account demonstrates the structuring dimension of religion, that ordering and unifying characteristic that, as Emile Durkheim (1915) noted, makes society possible and saves people from purposelessness and isolation. However, this excerpt also draws our attention to what was absent from religion in Durkheim's theory- the element of hegemony - by emphasizing the role of actors who fight against religious activism ("they," the secularist generals who implemented an anti-Islamist coup in 1997). Also buried in this account, buried under the pronoun "it," is the other side of the hegemonic equation: the actors whom the secularist generals blocked, those who "strengthen" religion - the Islamists. Islamists naturalized their power over workers like Dursun by giving a purpose and direction to their lives through building an alternative routine.

Society is structured, but this structuring is hegemonic rather than mechanical: there are interested actors who structure society in certain ways. In Sultanbeyli, these are the religious specialists (imams and instructors of religious schools) and the Islamists. These actors are active in mosques, teahouses, workplaces, and party headquarters, telling people to abide by the prayer times and not to miss any prayers, or actually monitoring them to make sure that they pray regularly. ${ }^{38}$ This is not all. As Islamists come to hold positions of power, this hegemonic regulation of everyday practices (and the flow of time) is even more structured, consensual, and consecrated, as can be seen in the case of municipal practices.

In the municipality of Sultanbeyli, the daily prayer was an inseparable part of life. Almost everybody took regular breaks to perform their prayers. More, the Islamist administrators asked the workers whether they had already prayed before giving them tasks, especially if these involved going to far away places. Workers of the municipality approvingly said that this would be impossible in other official workplaces. What religious scholars and Islamists propagate as duty elsewhere, had become a right here: prayer times constituted seemingly natural (or "divine") limits to the authority of the administrators, limits that softened the tone of their orders. Where praying regularly had become naturalized, Islamists could just lean against that naturalization to establish their hegemony, rather than blatantly imposing their worldview. In the case of the local municipality, at least, the hegemonic identity work of Islamism had born its political fruits: a major institution regulated people's lives in an Islamic way. Targeting everyday life had started to reverberate up to the state.

The residents desired to see regulation of time on a broader scale. Some of them wanted religious time to be enforced nationally. After the noon prayer one day, I joined a conversation between construction workers. One of them, who had worked for four and a half years in Saudi Arabia, praised the Saudi system:

They have a beautiful country. The Fridays are holidays. You cannot do any business on a Friday. More, when the call to prayer is heard on any other day, you have to quit all work. If you don't, they take you to the police station. But you do not have to pray. If you want, you can sit in a corner. Yet, until

\footnotetext{
$\overline{38}$ This is the element of "mutual surveillance" that Philip Gorski (2003) has shown to be central to other types of religious insurgency as well, such as Calvinism.
} 
everybody finishes the prayer, working is forbidden. And look at our country:

here, they would fire a man who performs his prayers!

Even though this characterization of the Saudi and Turkish regimes was not completely accurate, the other workers nodded approvingly, affirming the political perspective conveyed through this depiction. Some of the construction workers of the district had likewise worked in Saudi Arabia for Turkish or other firms. They also propagated similar views in Sultanbeyli. However, no legal organization in the district could voice this outlook openly, since defending an Islamic state or the application of Islamic law is illegal in Turkey. Despite this barrier, Islamists reproduced the desire for state power mostly through informal talk in teahouses and other venues.

Hence, Islamist mobilization is not simply about taking to the street, but constituting the actors. Time is one of the elements that are constitutive of actors, and Islamists (along with licensed religious specialists) reorganize time in everyday life. But its reorganization, this reshuffling of identity, also fosters desires for political power, urging us to go beyond any simple dichotomy between state and society, politics proper and identity politics. This is precisely so because it is only through state control that the practices structured by the Islamist movement can be decisively naturalized.

\section{Islamism's long walk through institutions}

The mobilization studied above is mostly concentrated in the capillaries of "society," even though it extends to the state. Yet, the Islamist impact on everyday life also manifests itself at the more institutional level, affecting the molecular workings of official and unofficial mosques, municipal and other public offices. This osmosis of the informal into the formal calls into question the categorical opposition between social movements that organize through formal channels and those that mobilize through informal networks and shared meanings (Melucci 1989; Wiktorowicz 2001). ${ }^{39}$

\section{Uses of the mosque}

The mosque is of one the central foci of the struggle over meanings and practices in Turkey. The state uses it to propagate secularist and nationalist messages. Indeed, the central authorities take special care to ensure that the Friday sermons transmit nationalist messages and modernist interpretations of Islam to the mosque

\footnotetext{
39 This binary opposition has a convoluted history in social movement studies. Tilly (1978) and others first emphasized associational and rationally organized forms of collective action that emerged in the nineteenth century (and differed from the informal gatherings of premodern mobilization) as a reaction to collective behavior theorists who focused on "irrational" crowd behavior (though Blumer, Smelser, and Turner and Killian had also studied the ultimate institutionalization of such behavior). Later social movement scholars brought informal networks back in without implying that they are irrational, but they also retained a binary opposition between informal and formal mobilization.
} 
communities in a way that will "resonate" (Snow and Benford 1988) with their universe of affection and discourse. Friday sermons are also sites of contestation in troubled times, making them central to the reproduction of secularist hegemony.

A clear example of this was the Friday sermon given in the central mosque of Sultanbeyli during the days of the anti-US protests all over Turkey, which followed the bombings of Afghanistan. Eight minibuses, a municipality bus, and two panzers full of armed policemen were waiting in front of the central mosque. The imam's sermon was meant to calm down the community, which had been infuriated by the military operation:

Wars have occurred in the time of the Prophet, they have occurred after him. They will occur after us. The thing for the Muslim to do is to pray for those who experience zulüm [undeserved violence or oppression] in war. Nothing will happen by shouting and screaming.

He uttered these sentences in a soft, paternalist tone, as if a teacher talking to idle students, as if sure of the affect they would produce. The crowd did not cause much trouble to the police after the sermon. The imam's words infuriated radical Islamists listening to the sermon, or who heard about it afterwards. But there was nothing they could do to counterbalance the power of the central mosque's imam. Such uses of the mosque block incipient Islamist mobilization and reinstate secularist power: they naturalize the existing state of affairs and reproduce obedience to the state.

On the other hand, central mosques have to compromise once in a while, in order to retain their crowds. One of the surest ways of managing discontent is letting the representatives of seemingly oppositional groups talk in Friday sermons. The leader of the Süleymancı community of Sultanbeyli used this political space to attack the interventions of the local governor during a Friday sermon in 2000:

The local governor brags: "I haven't left one person walking on the streets of Sultanbeyli with turban, cüppe [traditional robe], or şalvar [traditional baggy trousers]. I have left only two Qur'an schools, and closed down the rest." What kind of a sense of duty is this? ... This man has come to power with your vote [implying the nationalist parties who have appointed the local governor]. You, who have come here for prayer, have brought to duty a man who doesn't prostrate before God. God will summon you on dooms day and ask, "Account for it! Why have you brought the enemy of religion to the top?"

The guest imam, the leader of the Süleymancr community (one of the most powerful Islamic groups in Turkey), attacks the appointed local governor because of his policies that have targeted Islamic education and Islamic dress. He establishes a direct relation between voting and doomsday, the state and religion, and suggests that the community not vote for nationalist parties. ${ }^{40} \mathrm{He}$ also implies that only religious men are fit for posts such as the local governor.

\footnotetext{
${ }^{40}$ I have used the label "seemingly oppositional" for this community, since its stance with regard to the state is complex and appearances might be misleading. For example, one irony regarding this sermon was the community's reported electoral support for one of the parties that came to power after the elections in 1999. Moreover, an exclusively oppositional group would not be given a similar voice in official mosques.
} 
The sermons of the central mosque's imam and this guest imam reveal one dimension of religious mobilization (and demobilization). This is the level at which religion is consciously and explicitly political. Either the state uses it as an opiate to soothe the moral indignation of the people, or the religious opposition uses it as a resource for political mobilization against the power holders, as Morris's (1984) work suggested. In these examples, religion is instrumentally employed to produce secular and Islamic power. Religion is indeed a strategic and instrumental "resource" in some contexts.

The state targeted explicitly contentious uses of the mosque more than ever after the coup on the 28th of February, 1997. While money was being collected almost everyday in front of the mosques (for Qur'an schools, for construction of other mosques, etc.), after the coup money collection was restricted officially to once every two weeks. The permission of the Directorate of Religious Affairs was required for money collection. Yet, these rules were broken in many mosques and the community continued to contribute to religious activities. After 1997, the control over Friday sermons was very tight. In districts such as Sultanbeyli, where the imams of many mosques are community-employed rather than being appointed by the state, such control was only partially fruitful. Non-Islamist Muslims paid particular heed to going to Friday sermons in central mosques with official imams. Yet, Islamists in central locations took great pains to go to mosques with community-employed imams, when they had the time to walk or if they had cars. Islamists took advantage of such "opportunities" to spread their version of religion. Religion and its role in social movements (and official pressure on movements) at this (instrumentally strategic) level can be analyzed with the tools provided by political process theories (though an NSM scholar could reasonably argue that there are non-instrumental identity issues involved even in these examples).

However, this is only part of the story. The battle over religion is not only a fight about controlling a valuable resource, but also about regulating the structuring principles of everyday life. Religious hegemony involves the power to naturalize (or denaturalize) certain social arrangements, which brings together with it the naturalization of certain power relations. Consequently, it would be wise to look not only at whether and how imams espouse certain parties and organizations (rather than the secular state), but at how they naturalize or denaturalize social relations such as the places of men and women in urban life.

Even many appointed imams frequently focused on the separation of the sexes. For instance, during one Friday sermon, the officially appointed imam of one of the larger mosques of the district preached as follows:

Believers! Do not enter the homes of women the husbands of whom are not home. Do not create any situation which can invite adultery. Make sure your women cover themselves. But do not forget that you should also cover your eyes [avoid looking at women]. [Moreover,] covering is not the duty of only women. Therefore the reverse is also true: you should also take care to cover certain parts of your body and women should cover their eyes. ... The state is not fulfilling its duty. For example, in high schools, girls and boys sit next to each other! This is an invitation to sin. So at least you, believers, should do what you can do and pay attention to your covering. 
Sermons such as this one, quite frequent in the mosques of Sultanbeyli, brought about at one and the same time the denaturalization of the spatial arrangements of the official education system (and of the city at large), naturalization of Islamic arrangements and clothing, naturalization of Muslim men's control over Muslim women's bodies, and redefinition of the role of the state. The state's duty was redefined as enforcing the separation of the sexes. By implication, the secular state, which did not enforce it, was declared illegitimate. Also by implication, a complete and proper organization of everyday life required a re-organization of the state. These intertwined mechanisms exemplify the reconstitution of hegemony: the reorganization of power through the denaturalization of established everyday life patterns and the formation of an alternative everyday routine.

This regulation of everyday life was starker in mosques with unofficial imams. Fikret, the radical estate dealer, was among those residents who were quite dissatisfied with the imam of the central mosque. He and his friends frequently went to the alternative mosques of the district to support unofficial religious venues. One Friday, he invited me to go to one of these mosques, telling me "we would gain more sevap [merit]." We joined his business partner and a recent theology graduate (connected to them through a Qur'an study group) and went to a mosque in one of Sultanbeyli's remote neighborhoods. It was quite crowded. Because of the density, people were stepping on each other's feet, a situation one would encounter only twice a year in regular mosques (during the bayram/eid prayers, which are performed on religious holidays). It was so packed that people could hardly pray. The mosque itself was still under construction, and it was surprising to see so many people willing to be there under these abject conditions. As seen below, the community-employed imams give somewhat different messages from appointed imams not only politically but also at the everyday level. The imam (a Kurdish man with a long beard) was quite strict. He preached in a shouting tone:

The state is trying to instill a humanist religion under the guise of Islam. It is asking us to respect non-believers, whereas we shouldn't respect them.... Muslims forgot shariah, and they are employing stark naked women [women with miniskirts and sleeveless blouses] in order to attract customers. But, there is no need to be friends or do business with unbeliever customers [mümin olmayanlar, who would presumably be attracted by these women].... Muslims should Islamize their surroundings. Islam is not a religion that can be closed within the conscience; it has to organize life-in the workplace, in the apartment building, in employing people.

The secular state's rationale in not permitting imams to write their own sermons lies precisely in this propensity of many prayer leaders to naturalize a social order that is fundamentally at odds with the one the state naturalizes. Both the Islamist attendants of this mosque and the state actors who are trying to control these sermons perceive such sermons (and also the act of attending them) to be subversive of the state, even when they do not touch matters that have to do with the central government or its policy decisions. That is because these sermons spread an interpretation of Islam that hegemonically reorders life at all levels (respect of others, clothing, business choices, friendship, social responsi- 
bilities, etc.) and reinforces leadership by religious guides as an alternative to domination by secular officials.

I have looked at two kinds of uses of the mosque in this section. The first is openly political. The state and Islamists use the sermons to give political messages, to demobilize or mobilize the population. Yet, even these more "political" proclamations also (re)produce "meaning" and everyday practices: depending on the mosque and preacher, they naturalize war, certain types of clothing, expectations of piety from the rulers, etc. This intermeshing of naturalization with the openly political is what establishes hegemony. The mobilization in the second type of use is more subtle and less perceptible, but no less real. The second use is formative of actors through the regulation of everyday life. As seen above, this regulation is tighter in the mosques controlled and frequented by Islamists. Here we see that Islamists mobilize not in the sense of taking to the streets, but in a "subterranean politics" of frequenting mosques where social life is structured in the Islamist direction, and drawing people to these mosques. However, even this attempted regulation of everyday life is not only about "society" as separate from the state: it calls for the restructuring of the state and its policies as well.

My findings are in accordance with Saba Mahmood's study of Islamic mobilization in Egypt. Mahmood (2005) argues that everyday life is deeply politicized in the modern Middle East, and any transformation on this terrain incites political intervention. She points out, for example, that it would be wrong to take women involved in the Egyptian "mosque movement" (a grass-roots piety movement) at their word and believe that this is a non-political movement. As everyday life has been deeply politicized, their conduct interferes with the secularliberal project of the state. Therefore the state has either regulated the mosques where the movement is active (nationalized them and required formal training) or closed them down.

However, Mahmood's differentiation between the "political Islamism" of the parties and the religiosity of the mosque movement is too categorical. For instance, according to Mahmood, whereas the former defends the veil (as a symbol) to build an Islamic state, the latter defends it to create ethical conduct. Their difference in the use of the veil extends to their deployment of every other Islamic symbol. But in Turkey, the Islamist party, networks, and communities deployed Islam in both ways: they struggled for an Islamic order, while at the same time regulating everyday lives. There is a continuum rather than a sharp separation between the two types of religious activity, I would argue.

Secular and religious officials: duty and piety

The connection between subterranean mobilization and the state is even clearer when the practices of officials are involved. In Sultanbeyli, the everyday practices of the municipal and governmental officials were the focus of public scrutiny. The officials themselves were highly interested too in presenting the "correct" behaviors. Zübeyir was one of the top officials of the Sultanbeyli municipality and an ardent supporter of the Virtue Party. In his mid-forties, he was a graduate of one of the prestigious theology schools. When I entered his room one day in Ramadan (the fasting month of the Muslim calendar), a chanter was reciting the Qur'an on the radio. 
Zübeyir was following the chant by going over the lines of a Qur'an in Arabic script with his fingers and eyes. After I reciprocated his greeting, I told him I could come later, as I did not want to disturb the ritual. Reading the Qur'an (especially in the original Arabic) has great sevap (merit) in Islam, but it brings more sevap during the Ramadan. Finishing the whole book once (hatim indirmek) during this month is considered to be an even greater sevap. Following radio and television programs that air chanters during Ramadan is an opportunity to gain this sevap. "No, it's almost over," he said, letting go of neither the merit nor a possible impact on social science.

As I was waiting for him, I took a look at the daily newspaper on his desk. The headlines were about a case of fraud in one of the major banks of Turkey. In the last decade, bank scandals had become a common occurrence in this country: top officials of the secular state were frequently involved in illegally transferring the funds of public banks to private parties, or "saving" bankrupt private banks by legally transferring public funds to these banks, which had (the public suspicion was) gone bankrupt on purpose to receive help from the state.

After the program was over, I said "I guess you are going to finish the whole book in Ramadan." Zübeyir responded: "One has to perform good deeds. [Pointing at the newspaper] Look at those men. They are pillaging the banks!" An official in the municipality thus counterposed his ritualistic practice to the practice of other, secular officials who spend their times performing or helping fraud. The implication was that if people who carry out "good deeds" (amel-us salihati, a Qur'anic phrase) controlled the state, there would be less corruption. This belief was frequently mentioned in teahouses and other informal conversations or, as here, implicitly reproduced. This opposition between the righteous and the corrupt also justifies the use of public office and the working hours of the day for religious purposes (to which the secularists in Turkey are opposed and which they see as preparation for the Islamist usurpation of the state). Again, the differences in the flow of daily life are manipulated to reproduce the distinctions between the religious and the secular, "us" and "them," and imply the need for a different political regime and society. In short, the way Islamists give meaning to basic rituals goes beyond piety and is interwoven with the reconstruction of hegemony: the naturalization of an alternative set of power holders who should ideally replace the existing ones.

These implicit or non-public challenges to secular officials sometimes become explicit and public. The central government in Ankara had recently removed one of the former imams of the central mosque in Sultanbeyli from his duty. There were several speculations about the reasons of this action. Given the officially delicate nature of the issue, it was not possible to determine with certitude the actual motivation behind it. However, one of the commonly told stories went as follows. This former imam, himself appointed by the central government, criticized the local governor quite frequently because of his secularist policies. The local governor first warned and then threatened him. The imam responded by saying "I am only propagating Islam; I am not doing anything else. We are not afraid of anybody but God." The residents of the district reported that this imam also gave one decisive speech during a funeral. He allegedly said:

I might be the state's imam here, but I wouldn't lead the funeral prayer of an irreligious man. I am making the call to the prayer five times a day. If a man 
does not come even once, why should I lead his funeral prayer? Why should I lead the funeral prayer of a man who doesn't go to the Friday prayer even once a month? Sons and nephews of deceased people bring them and tell me they were Muslims, so I lead their funeral prayers. It is their sin if they are lying. But if I actually know that the man is not a [practicing] Muslim, I would not lead the prayer.

These residents interpreted this speech as a threat against the local governor, who did not go to the mosque. The imam was implying that he would not lead the local governor's funeral prayer. "This was a speech against the state," these residents said, suggesting that not only the person of the local governor, but the regime he represented was put into question by the speech. These stories were circulated especially by construction workers in teahouses. The better off of the district, especially those who wanted peaceful relations between the residents and the local government, between religion and state, said that the imam wanted to go somewhere else and the central government only helped him! Another argument was that he had retired and then left the district. While I could not verify any one of these three stories, what is significant in terms of the argument being made here is that the construction workers who sympathized with Islamism saw a direct relation between everyday religious observance and the legitimacy of an official's rule over them. These stories not only put pressure on the officials of the district to be more observant, they also envisioned an ideal order where only certain people with certain daily routines would be able to become officials. They thus reinforced Islamist hegemony by defining the ideal daily conduct of rulers, as well as of regular Muslims (a person is not worthy of a funeral ceremony if he does not pray). Just as targeting everyday life reverberated up to the state in some of the examples above, targeting the state reverberated down to society in this case.

\section{Conclusion}

Through the de-naturalization of secular life and traditional Islam and the attempted naturalization of an alternative understanding of religion, Islamists had transformed teahouses and municipalities by the summer of 2002, and spread unofficial mosques throughout remote neighborhoods. The movement had not yet re-created local governments and other state institutions as it pleased, but it instilled in ordinary citizens the desire to see pious rulers. ${ }^{41}$ These changes did not come about through street action, strikes, and petitions, but as a result of silent movement work on everyday practices.

\footnotetext{
${ }^{41}$ In 2007, five years after this research was completed, tensions over whether Turkey could have a pious president plunged the country into a deep crisis. The conservative Justice and Development Party (AKP) government put forth a practicing Muslim as its presidential candidate and Islamist intellectuals (as well as the speaker of the parliament) argued that from now on Turkey would have only pious presidents. The secularist military used both moves as an excuse to intervene in politics and call for early elections. The AKP government emerged out of the elections as a stronger party and had its practicing candidate elected.
} 
The practice of Islamism in Sultanbeyli demonstrates that some social movements cannot be properly understood unless their identity work (not only on notions of "us," but also on alternative daily practices) and their relation to the properly political realm are handled as inseparable parts of a larger hegemonic project. Islamists use Islam as a guide in economic and religious life, and believe that this conduct will lead to a specific type of state (but the development of this conduct also depends on the state, as these actors recognize). This case exemplifies how daily conduct can be part and parcel of political struggles.

As the conversations and routines of Islamists in Sultanbeyli also demonstrate, social movements are structured and their subjects constituted not only in organizations and on the street, but also through countless everyday interactions that shape the daily conduct of participants. This constitution challenges the boundaries between society and state, identity and strategy, culture and structure. Islamists see developing their lifestyle (praying, fasting, behaving modestly, and being frugal) not only as developing a politics of identity disengaged from the state and from properly political realities, but as a struggle against imperialism. Islamist interventions produce an Islamic architectural structure, which is one of the cultural goals of the movement. Yet, this architectural structure further structures Islamic mobilization. Islamists also naturalize an alternative order of things by reorganizing time in people's lives, especially around prayer times. The reorganization of time and daily activities, though seemingly "social" only, involves the hand of the state (and other major political institutions like municipalities), since actors are aware that institutional reordering of time is necessary for a durable reorganization of life (e.g., for a sustained reorganization of everyday activities around prayer times). The case of Islamism in Turkey should thus make us rethink the theoretical separations that are made in the social movement literature.

The boundaries between society and state are blurred not only at the everyday level, but also at the level of institutions. In Sultanbeyli, mosques are used as resources for Islamist mobilization, just like churches were among the key resources in the civil rights movement in the United States. However, the mosque is not only a "resource" for Islamism; it is a primary site for the construction of Islamism as a movement and the production of Islamist subjects. Islamists in this district use the mosques to denaturalize the secular life instituted by the republic and to naturalize an emergent Islamic lifestyle, which they think should also be reinforced by the state. If religious institutions have an identity component as well as their bureaucratic and resource functions, so do political offices. The goal of the Islamist movement is the production of subjects who will have different daily conducts, different rituals, and therefore different "internalized political programs" (Bourdieu 1984, pp. 424-426) than the secularist officials. The Islamist residents of the district share this vision with the Islamist administrators and believe that only practicing people are really fit to rule. Hence, the creation of an Islamist identity in Sultanbeyli is not separate from envisioning a different state. These observations suggest that social movement studies can benefit from focusing on how institutions constitute actors and how the reorganization of their daily life acts back upon the state.

The case at hand might imply that the intermeshing of the political and the everyday is specific to Islamic movements. Nevertheless, an exchange between Michael Young (2002) and Charles Tilly (2002) demonstrates that it might be 
problematic to pigeonhole movements into state-oriented and society-oriented even in the paradigmatic case of the United States. ${ }^{42}$ This instructive debate is somewhat derailed by the participants' insistence on deciding whether nineteenth-century temperance and anti-slavery movements primarily targeted the state or society. I suggest that we would have a more productive way of looking at these movements as constitutions of hegemony in the United States, with the understanding that hegemonic moves might shift their focus to the individual, society or state depending upon circumstances and the social context. ${ }^{43}$ In this vein, one could argue that these movements' provisional concentration on conquering society, which Young so elegantly depicts, was but a war of position that foreshadowed the war(s) of movement to come. ${ }^{44}$ Currently, the United States might be experiencing a similar movement that simultaneously targets state and society through working on everyday life - the new Christian Right.

Drawing on Habermas's and Touraine's work, Cohen (1985, pp. 668-669, 708709) has argued that the main contribution of the Western New Left in the 1960s was to focus mostly on everyday life and civil society. But she adds that this was wedded to an old Marxist, revolutionary desire for total rupture with bourgeois society. New social movements, she concludes, have come to themselves by shedding away this final "totalizing" desire. Movements that both transformed everyday life and targeted the state were brief parentheses in the history of social movements; they were precursors of the total transition to non-state-oriented movements, it would seem. However, recent developments - ranging from the rise of Islamic movements to that of the Christian Right-demonstrate that even though the Western left may have abandoned this ground, new forces all over the globe have claimed it. These developments may suggest that movements that simultaneously target the state and everyday life are endemic to modernity rather than momentary lapses of reason.

To use that metaphor from the North American political scene once again, Islamists both march on the "White House" and take over the "English Department." They both aim to hold governmental power and to shape people's daily lives and identity. Islamists, in their practice if not in their discourse, do not oppose identity politics to politics proper. Is there a good reason why social scientists should?

\footnotetext{
${ }^{42}$ Also see Javier Auyero (2003), Georgi Derluguian (2005), Davis (1999), and Raka Ray (1999) for movements that problematize the state/society distinction in contexts as varied as Latin America, South Asia, and the Caucusus.

${ }^{43}$ Actually, long before this debate took place, Mary Bernstein (1997) had pointed out that gay and lesbian movements in the United States shifted from emphasizing identity to targeting the state depending upon the moves of the state and the anti-gay opposition. While my findings tend to be parallel to Bernstein's, in that we both emphasize the context-dependence of state- or society-orientation of movements, I focus more on everyday practices, their mechanisms, and the internal dynamics of the identity field, whereas Bernstein seems ultimately to reduce the dynamics of identity to political context. It should also be noted that even though the gay and lesbian movements in the United States might target both society and state at times, they mostly do not seek to establish hegemony in the wider society.

44 This conceptual distinction comes from Gramsci (1971) who pointed out that transformative politics in countries with strong intermediary institutions have to fight for controlling civil society ("war of position") before attempting to capture state power or shape state policy ("war of movement").
} 
Acknowledgments I thank Irene Bloemraad, Michael Burawoy, Marion Fourcade-Gourinchas, Dawne Moon, Raka Ray, Dylan Riley, Sandra Smith, Ann Swidler, and Charles Tilly for their comments.

Open Access This article is distributed under the terms of the Creative Commons Attribution Noncommercial License which permits any noncommercial use, distribution, and reproduction in any medium, provided the original author(s) and source are credited.

\section{References}

Alexander, C. (2000). Opportunities, organizations, and ideas: Islamists and workers in Tunisia and Algeria. International Journal of Middle East Studies, 32, 465-490.

Auyero, J. (2003). Contentious lives: Two Argentine women, two protests, and the quest for recognition. Durham: Duke University Press.

Auyero, J. (2004). When everyday life, routine politics, and protest meet. Theory and Society, 33, 417-441.

Bellah, R. N., Madsen, R., Sullivan, W. M., Swidler, A., \& Tipton, S. M. (1985). Habits of the heart: Individualism and commitment in American life. Berkeley: University of California Press.

Benford, R. D. (1993). 'You could be the hundredth monkey': collective action frames and vocabularies of motive within the nuclear disarmament movement. Sociological Quarterly, 34, 195-216.

Bernstein, M. (1997). Celebration and suppression: the strategic uses of identity by the lesbian and gay movement. American Journal of Sociology, 103, 531-565.

Billings, D. B. (1990). Religion as opposition: a Gramscian analysis. American Journal of Sociology, 96, 1-31.

Bourdieu, P. ((1972) 1977). Outline of a theory of practice. New York: Cambridge University Press.

Bourdieu, P. ((1979) 1984). Distinction: A social critique of the judgement of taste. Cambridge: Harvard University.

Bourdieu, P. ((1980) 1990). The logic of practice. Stanford: Stanford University Press.

Brubaker, R., \& Cooper, F. (2000). Beyond "identity". Theory and Society, 29, 1-47.

Burawoy, M. (1998). The extended case method. Sociological Theory, 16, 4-33.

Burawoy, M., Burton, A., Ferguson, A. A., Fox, K. J., Gamson, J., Hurst, L., et al. (1991). Ethnography unbound: Power and resistance in the modern metropolis. Berkeley: University of California Press.

Clark, J. A. (2004). Islamist women in Yemen: informal nodes of activism. In Q. Wiktorowicz (Ed.), Islamic activism: A social movement theory approach (pp. 164-184). Bloomington: Indiana University Press.

Clemens, E. S. (1993). Organizational repertoires and institutional change: women's groups and the transformation of American politics, 1890-1920. American Journal of Sociology, 98, 755-798.

Clemens, E. S. (1996). Organizational form as frame: collective identity and political strategy in the American labor movement, 1880-1920. In D. McAdam, J. D. McCarthy \& M. N. Zald (Eds.), Comparative perspectives on social movements: Opportunities, mobilizing structures, and cultural framings (pp. 205-226). New York: Cambridge University Press.

Cohen, J. L. (1985). Strategy or identity: new theoretical paradigms and contemporary social movements. Social Research, 52, 663-716.

Cohen, J. L., \& Arato, A. (1992). Civil society and political theory. Cambridge: MIT Press.

Davis, D. E. (1999). The power of distance: re-theorizing social movements in Latin America. Theory and Society, 28, 585-638.

Davison, A. (1998). Secularism and revivalism in Turkey: A hermeneutic reconsideration. New Haven \& London: Yale University Press.

de Certeau, M. ((1974) 1984). The practice of everyday life. Berkeley: University of California Press.

Derluguian, G. (2005). Bourdieu's secret admirer in the Caucasus: A world-systems biography. Chicago: University of Chicago Press.

Durkheim, E. (1915). The elementary forms of religious life. New York: Macmillan Company.

Elias, N. ((1939) 2000). The civilizing process: sociogenetic and psychogenetic investigations. Oxford; Cambridge: Blackwell Publishers

Emirbayer, M., \& Goldberg, C. A. (2005). Pragmatism, Bourdieu, and collective emotions in contentious politics. Theory and Society, 34, 469-518.

Epstein, S. (1996). Impure science: AIDS, activism, and the politics of knowledge. Berkeley: University of California Press. 
Fine, G. A. (1995). Public narration and group culture: discerning discourse in social movements. In H. Johnston \& B. Klandermans (Eds.), Social movements and culture (pp. 127-143). Minneapolis: University of Minnesota Press.

Gamson, W. (1975). The strategy of social protest. Homewood, Ill.: Dorsey Press.

Gamson, W. (1988). Political discourse and collective action. International Social Movement Research, 1, 219-244.

Gamson, W. A., \& Meyer, D. S. (1996). Framing political opportunity. In D. McAdam, J. D. McCarthy \& M. N. Zald (Eds.), Comparative perspectives on social movements: Opportunities, mobilizing structures, and cultural framings (pp. 275-290). New York: Cambridge University Press.

Gaventa, J. (1982). Power and powerlessness: Quiescence and rebellion in an Appalachian valley. Urbana: University of Illinois Press.

Gitlin, T. (1995). The twilight of common dreams: Why America is wracked by culture wars. New York: Metropolitan Books.

Goffman, E. (1959). The presentation of self in everyday life. New York: Anchor Books.

Göle, N. (1996). The forbidden modern: Civilization and veiling. Ann Arbor: University of Michigan Press.

Goodwin, J., \& Jasper, J. M. (1999). Caught in a winding, snarling vine: the structural bias of political process theory. Sociological-Forum, 14, 27-54.

Goodwin, J., \& Jasper, J. M. (eds). (2004a). Rethinking social movements: Structure, meaning, and emotion. Lanham: Rowman \& Littlefield.

Goodwin, J., \& Jasper, J. M. (2004b). Trouble in paradigms. In J. Goodwin \& J. M. Jasper (Eds.), Rethinking social movements: Structure, meaning, and emotion (pp. 75-93). Lanham: Rowman \& Littlefield.

Goodwin, J., Jasper, J. M., \& Polletta, F. (2001). Passionate politics: Emotions and social movements. Chicago: University of Chicago Press.

Gorski, P. (2003). The disciplinary revolution: Calvinism and the rise of the state in early modern Europe. Chicago: University of Chicago Press.

Gould, D. (2002). Life during wartime: emotions and the development of ACT UP. Mobilization, 7, 177-200.

Gramsci, A. (1971). Selections from the prison notebooks of Antonio Gramsci. London: Lawrence and Wishart.

Habermas, J. (1987). The theory of communicative action. Cambridge: MIT Press.

Habermas, J. (1996). Between facts and norms: Contributions to a discourse theory of law and democracy. Cambridge: MIT Press.

Hafez, M. M. (2003). Why Muslims rebel: Repression and resistance in the Islamic world. Boulder: Lynne Rienner Publishers.

Ișık, O., \& Pınarcıŏlu, M. M. (2001). Nöbetleşe yoksulluk: Gecekondulaşma ve kent yoksulları: Sultanbeyli örneği. Istanbul: İletișim.

Jasper, J. M. (1997). The art of moral protest: Culture, biography, and creativity in social movements. Chicago: University of Chicago Press.

Jasper, J. M. (2004). A strategic approach to collective action: looking for agency in social movement choices. Mobilization, 9, 1-16.

Jenkins, J. C., \& Perrow, C. (1977). Insurgency of the powerless: farm worker movements (1946-1972). American Sociological Review, 42, 249-268.

Johnston, H., \& Klandermans, B. (eds). (1995). Social movements and culture. Minneapolis: University of Minnesota Press.

Keyder, Ç. (ed). (1999). Istanbul: Between the local and the global. Lanham: Rowman and Littlefield Publishers.

King, D. (2004). Operationalizing Melucci: metamorphosis and passion in the negotiation of activists' multiple identities. Mobilization, 9, 73-92.

Kriesi, H., Koopmans, R., Duyvendak, J. M., \& Giugni, M. G. (1995). New social movements in Western Europe: A comparative analysis. Minneapolis: University of Minnesota Press.

Kuru, A. T. (2005). Globalization and diversification of Islamic movements: three Turkish cases. Political Science Quarterly, 120, 253-274.

Kurzman, C. (1996). Structural opportunities and perceived opportunities in social-movement theory: evidence from the Iranian Revolution of 1979. American Sociological Review, 61, 153-170.

Laitin, D. D. (1986). Hegemony and culture: Politics and religious change among the Yoruba. Chicago: University of Chicago Press.

Lefebvre, H. ((1947) 1991). Critique of everyday life. London; New York: Verso.

Lichterman, P. (1996). The search for political community: American activists reinventing commitment. Cambridge and New York: Cambridge University Press. 
Lichterman, P. (1998). What do movements mean? The value of participant-observation. Qualitative Sociology, 21, 401-418.

Mahmood, S. (2005). Politics of piety: The Islamic revival and the feminist subject. Princeton: Princeton University Press.

Mardin, Ș. (1989). Religion and social change in modern Turkey: The case of Bediüzzaman Said Nursi. Albany: State University of New York Press.

McAdam, D. (1982). Political process and the development of black insurgency. Chicago: University of Chicago Press.

McAdam, D. (1988). Freedom summer. New York: Oxford University Press.

McAdam, D., Tarrow, S., \& Tilly, C. (2001). Dynamics of contention. New York: Cambridge University Press.

McAdam, D., Sampson, R. J., Weffer, S., \& MacIndoe, H. (2005). "There will be fighting in the streets": the distorting lens of social movement theory. Mobilization, 10, 1-18.

McCarthy, J. D., \& Zald, M. (1977). Resource mobilization and social movements: a partial theory. American Journal of Sociology, 82, 1212-1241.

Meeks, C. (2001). Civil society and the sexual politics of difference. Sociological Theory, 19, $325-343$.

Melucci, A. (1989). Nomads of the present: Social movements and individual needs in contemporary society. Philadelphia: Temple University Press.

Melucci, A. (1996a). Challenging codes: Collective action in the information age. Cambridge; New York: Cambridge University Press.

Melucci, A. (1996b). The playing self: Person and meaning in the planetary society. Cambridge; New York: Cambridge University Press.

Meyer, D. S. (2002). Opportunities and identities: bridge-building in the study of social movements. In D. S. Meyer, N. Whittier \& B. Robnett (Eds.), Social movements: Identity, culture, and the state (pp. 321). Oxford; New York: Oxford University Press.

Meyer, D., \& Staggenborg, S. (1996). Movements, countermovements, and the structure of political opportunity. American Journal of Sociology, 101, 1628-1660.

Meyer, D. S., Whittier, N., \& Robnett, B. (eds). (2002). Social movements: Identity, culture, and the state. Oxford; New York: Oxford University Press.

Mitchell, T. (1999). Society, economy, and the state effect. In G. Steinmetz (Ed.), State/culture: Stateformation after the cultural turn (pp. 76-97). Ithaca, N.Y.: Cornell University Press.

Moon, D. (2004). God, sex, and politics: Homosexuality and everyday theologies. Chicago: University of Chicago Press.

Morris, A. D. (1984). The origins of the civil rights movement: Black communities organizing for change. New York: Free Press.

Mueller, C. M. (1992). Building social theory. In A. D. Morris \& C. M. Mueller (Eds.), Frontiers in social movement theory (pp. 2-25). New Haven: Yale University Press.

Munson, Z. (2001). Islamic mobilization: social movement theory and the Egyptian Muslim Brotherhood. Sociological Quarterly, 42, 487-510.

Oberschall, A. (1973). Social conflict and social movements. Englewood Cliffs., N.J: Prentice-Hall.

O'Brien, K. J. (2003). Neither transgressive nor contained: Boundary-spanning contention in China. Mobilization, 8, 51-64.

Offe, C. (1985). New social movements: challenging the boundaries of institutional politics. Social Research, 52, 817-886.

Özyürek, E. (2006). Nostalgia for the modern: State secularism and everyday politics in Turkey. Durham: Duke University Press.

Parsa, M. (1989). Social origins of the Iranian Revolution. New Brunswick and London: Rutgers University Press.

Perry, E. J. (2002). Moving the masses: emotion work in the Chinese Revolution. Mobilization, 7, 111128.

Piven, F. F., \& Cloward, R. A. (1977). Poor people's movements: Why they succeed, how they fail. New York: Pantheon Books.

Polletta, F. (1998a). Contending stories: narrative in social movements. Qualitative Sociology, 21, 419446.

Polletta, F. (1998b). 'It was like a fever...': Spontaneity and identity in collective action. Social Problems, $45,137-159$.

Polletta, F. (2002). Freedom is an endless meeting: Democracy in American social movements. Chicago: University of Chicago Press.

Polletta, F. (2004). Culture is not just in your head. In J. Goodwin \& J. M. Jasper (Eds.), Rethinking social movements: Structure, meaning, and emotion (pp. 97-110). Lanham: Rowman \& Littlefield. 
Polletta, F. (2006). It was like a fever: Storytelling in protest and politics. Chicago: University of Chicago Press.

Ray, R. (1999). Fields of protest: Women's movements in India. Minneapolis: University of Minnesota Press.

Sarıbay, A. Y. (1985). Türkiye'de modernleşme, din, ve parti politikası: Milli Selâmet Partisi örnek olayı. Istanbul: Alan.

Schurman, R., \& Munro, W. (2006). Ideas, thinkers, and social networks: the process of grievance construction in the anti-genetic engineering movement. Theory and Society, 35, 1-38.

Scott, J. C. (1985). Weapons of the weak: Everyday forms of peasant resistance. New Haven: Yale University Press.

Singerman, D. (2004). The networked world of Islamist social movements. In Q. Wiktorowicz (Ed.), Islamic activism: A social movement theory approach (pp. 143-163). Bloomington: Indiana University Press.

Smith, D. E. (1987). The everyday world as problematic: A feminist sociology. Boston: Northeastern University Press.

Snow, D. A., \& Benford, R. D. (1988). Ideology, frame resonance, and participant mobilization. International Social Movement Research, 1, 197-217.

Snow, D. A., Rochford, E. B., Jr., Worden, S. K., \& Benford, R. D. (1986). Frame alignment processes, micromobilization, and movement participation. American Sociological Review, 51, 464-481.

Steinberg, M. (1998). Tilting the frame: Considerations on collective action framing from a discursive turn. Theory and Society, 27, 845-872.

Steinberg, M. (1999). Fighting words: Working-class formation, collective action, and discourse in early nineteenth-century England. Ithaca and London: Cornell University Press.

Steinberg, M. (2004). The intellectual challenges of toiling in the vineyard. In J. Goodwin \& J. M. Jasper (Eds.), Rethinking social movements: Structure, meaning, and emotion (pp. 121-133). Lanham: Rowman \& Littlefield.

Swidler, A. (1995). Cultural power and social movements. In H. Johnston \& B. Klandermans (Eds.), Social movements and culture (pp. 25-40). Minneapolis: University of Minnesota Press.

Tarrow, S. (1993). Modular collective action and the rise of the social movement: why the French Revolution was not enough. Politics \& Society, 21, 69-90.

Tarrow, S. ((1994) 1998). Power in movement: Social movements, collective action and mass politics in the modern state. Cambridge: Cambridge University Press.

Taylor, V. (1989). Social movement continuity: The women's movement in abeyance. American Sociological Review, 54, 761-775.

Taylor, V., \& Whittier, N. E. (1992). Collective identity in social movement communities: Lesbian feminist mobilization. In A. D. Morris \& C. M. Mueller (Eds.), Frontiers in social movement theory (pp. 104-129). New Haven: Yale University Press.

Taylor, V., \& Whittier, N. E. (1995). Analytical approaches to social movement culture: The culture of the women's movement. In H. Johnston \& B. Klandermans (Eds.), Social movements and culture (pp. 163-187). Minneapolis: University of Minnesota Press.

Tilly, C. (1978). From mobilization to revolution. Reading, Massachusetts: Addison-Wesley.

Tilly, C. (1982). Britain creates the social movement. In J. E. Cronin \& J. Schneer (Eds.), Social conflict and the political order in modern Britain (pp. 21-51). London: Croom Helm.

Tilly, C. (1984). Social movements and national politics. In C. Bright \& S. Harding (Eds.), State making and social movements: Essays in history and theory (pp. 297-317). Ann Arbor: University of Michigan Press.

Tilly, C. (1986). The contentious French. Cambridge, Mass: Belknap Press.

Tilly, C. (1995a). Popular contention in Great Britain, 1758-1834. Cambridge: Harvard University Press.

Tilly, C. (1995b). Contentious repertoires in Great Britain, 1758-1834. In M. Traugott (Ed.), Repertoires and cycles of collective action (pp. 15-42). Durham, NC: Duke University Press.

Tilly, C. (2002). Comment on Young: Buried gold. American Sociological Review, 67, 689-692.

Touraine, A. (1981). The voice and the eye: An analysis of social movements. Cambridge; New York: Cambridge University Press.

Tuğal, C. (2006). The appeal of Islamic politics: ritual and dialogue in a poor district of Turkey. Sociological Quarterly, 47, 245-273.

Tuğal, C. (2007). NATO's Islamists: hegemony and Americanization in Turkey. New Left Review, 44, 5-34.

Voss, K. (1996). The collapse of a social movement: The interplay of mobilizing structures, framing, and political opportunities in the Knights of Labor. In D. McAdam, J. D. McCarthy \& M. N. Zald (Eds.), 
Comparative perspectives on social movements: Opportunities, mobilizing structures, and cultural framings (pp. 227-258). New York: Cambridge University Press.

White, J. (2002). Islamist mobilization in Turkey: A study in vernacular politics. Seattle: University Of Washington Press.

Whittier, N. (1995). Feminist generations: The persistence of the radical women's movement. Philadelphia: Temple University Press.

Wickham, C. R. (2002). Mobilizing Islam: Religion, activism, and political change in Egypt. New York: Columbia University Press.

Wiktorowicz, Q. (2001). The management of Islamic activism: Salafis, the Muslim Brotherhood, and state power in Jordan. Albany, NY: State University of New York Press.

Wiktorowicz, Q. (ed). (2004). Islamic activism: A social movement theory approach. Bloomington: Indiana University Press.

Yavuz, M. H. (2003). Islamic political identity in Turkey. Oxford and New York: Oxford University Press.

Yilmaz, I. (2003). Non-recognition of post-modern Turkish socio-legal reality and the predicament of women. British Journal of Middle Eastern Studies, 30, 25-41.

Young, M. P. (2002). Confessional protest: The religious birth of U.S. national social movements. American Sociological Review, 67, 660-688.

Zald, M. (1996). Culture, ideology, and strategic framing. In D. McAdam, J. D. McCarthy \& M. N. Zald (Eds.), Comparative perspectives on social movements: Opportunities, mobilizing structures, and cultural framings (pp. 261-274). New York: Cambridge University Press.

Cihan Tuğal is an Assistant Professor of Sociology at UC Berkeley. He is the author of Passive Revolution: Absorbing the Islamic Challenge to Capitalism (Stanford University Press, 2009). His previous research was published in Economy and Society ("Islamism in Turkey: Beyond Instrument and Meaning," 2002), the New Left Review ("NATO's Islamists: Hegemony and Americanization in Turkey," 2007, and "The Greening of Istanbul," 2008), and the Sociological Quarterly ("The Appeal of Islamic Politics: Ritual and Dialogue in a Poor District of Turkey," 2006). He is currently working on the development of neo-liberal Islamic ethics in Turkey, Egypt, and Iran. 